\title{
Raised marine sequences of Lanzarote and Fuerteventura revisited - a reappraisal of relative sea-level changes and vertical movements in the eastern Canary Islands during the Quaternary
}

\author{
Cari Zazo ${ }^{\mathrm{a}, *}$, José Luis Goy ${ }^{\mathrm{b}}$, Claude Hillaire-Marcel ${ }^{\mathrm{c}}$, Pierre-Yves Gillot ${ }^{\mathrm{d}}$, Vicente Soler ${ }^{\mathrm{e}}$, \\ José Ángel González ${ }^{\mathrm{b}}$, Cristino J. Dabrio ${ }^{\mathrm{f}}$, Bassam Ghaleb ${ }^{\mathrm{c}}$ \\ ${ }^{a}$ Departamento de Geologia, Museo Nacional de Ciencias Naturales-CSIC, 28006-Madrid, Spain \\ ${ }^{\mathrm{b}}$ Departamento de Geología, Facultad de Ciencias, Universidad, 37008-Salamanca, Spain \\ ${ }^{\mathrm{c}}$ Université du Québèc à Montrèal, GEOTOP-UQAM, Montrèal, Canada H3C 3 P8 \\ ${ }^{\mathrm{d}}$ Lab. de Geochronologie (UPS-IPGP), Sciences de la Terre, Université du Paris Sud, 91405 Orsay, France \\ ${ }^{\mathrm{e}}$ Instituto de Productos Naturales y Agrobiología. Estación Volcanológica de Canarias (CSIC), 38080-La Laguna, Tenerife, Spain \\ ${ }^{\mathrm{f}}$ Departamento de Estratigrafia and Instituto de Geología Económica-CSIC, Universidad Complutense, 28040-Madrid, Spain
}

\begin{abstract}
Systematic mapping and morphosedimentary analysis of Fuerteventura and Lanzarote Islands supported by laboratory techniques (U-series mostly by TIMS, ${ }^{14} \mathrm{C}$ analysis and allo-isoleucine measurements on biogenic carbonates from raised marine deposits, paleomagnetic and a few $\mathrm{K} / \mathrm{Ar}$ measurements on volcanic formations related to marine deposits) provide a basis for constraining the age of Late Cainozoic marine units. The most complete sequences of raised marine terraces are found at similar elevations in both islands. They include up to 12 marine terraces (Episodes) at elevations between $0 \mathrm{~m}$ and $70 \mathrm{~m}$ above mean sea level (asl). At least six terraces should be of Quaternary age, and more recent than 1.2 Myr. Throughout the whole marine sequence with the exception of the Holocene terrace, the warm fauna assemblage is characterized by the presence of Ostrea virleti, Nerita emiliana, and Strombus (S. cf. coronatus-S. cf. bubonius). However, there is a major change, highlighted by the disappearance of the first two species, below the 8-10 m terrace, that could possibly correspond to MIS 11. K-Ar measurements allow an estimate for mean uplift rate of $1.7 \mathrm{~cm} / \mathrm{ka}$ during the last million years. The present elevation of the Last Interglacial deposits (about 1 and $2 \mathrm{~m}$ asl) shows discontinuous vertical movements with possibly a reverse trend since MIS 9 in eastern Canary Islands.
\end{abstract}

\section{Introduction}

Many papers have investigated the raised marine terraces in the volcanic Archipelago of Canary Islands (Fig. 1) with particular interest in the islands of Lanzarote and Fuerteventura (Figs. 2 and 3). Driscoll et al. (1965), Tinkler (1966), Crofts (1967), Lecointre et al. (1967) and Hernández-Pacheco (1969) cited Quaternary marine terraces and described several levels at elevations ranging from +55 to $0 \mathrm{~m}$. Crofts (1967) recognized seven terraces in Fuerteventura, whereas Driscoll et al. (1965) and Tinkler (1966) registered six in Lanzarote at very similar elevations. As the faunal content of many of these layers included Strombus bubonius and other warm species, Hernández-Pacheco (1969) concluded that $S$. bubonius (classification by Cuerda and Álvarez-Sánchez) occurred in all the marine terraces, particularly in Los Ajaches area (Lanzarote).

Some of the terraces were stratigraphically related to volcanic materials of Quaternary age and they were used, together with older marine units placed at topographically higher elevations $(>55 \mathrm{~m})$ and $\mathrm{K} / \mathrm{Ar}$ dating, to establish (Fuster et al., 1968a,b) the chronology of subaerial volcanic series.

Meco (1977) studied the morphologic differentiations of Strombus shells and reinterpreted the faunal content of the marine terraces, concluding that the specimens of $S$. bubonius described by the former authors were actually Srombus coronatus, and that marine terraces bearing $S$. bubonius occurred only at elevations below 
$+5 \mathrm{~m}$. Meco (1977) also revised the warm fauna that accompanied Strombus concluding that the fauna at the time of $S$. coronatus lived in warmer waters than $\operatorname{did} S$. bubonius. Meco and Stearns (1981) used two new K/Ar

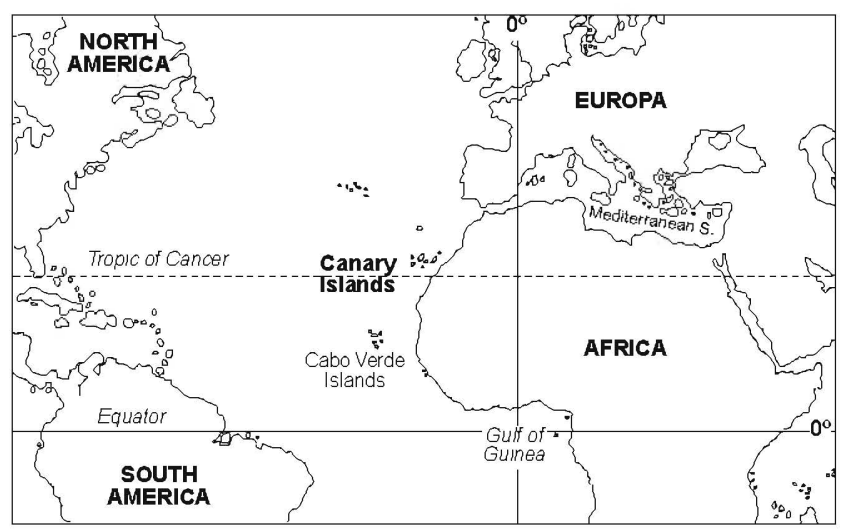

Fig. 1. Location map of the Canary Islands archipelago. data in Fuerteventura and one in Lanzarote, to suggest that all previously described pre-Holocene raised marine terraces assumed to be of Quaternary age could be actually grouped into two terraces. The older is of Early Pliocene age, with $S$. coronatus, Nerita emiliana, Ostrea virleti, etc. and occurs between $\sim 60$ and $\sim 7 \mathrm{~m}$ asl. The more recent terrace is of Late Pleistocene age and bears $S$. bubonius; it is always placed at elevations below $5 \mathrm{~m}$. The same criterion has been held in more recent papers (Meco, 1987; Meco et al., 1997) assuming that terraces containing S. coronatus are of Messinian (Mio-Pliocene) age whereas those bearing $S$. bubonius correspond to MIS 5e. Meco and Stearns (1981) justified the great variability of elevations of sites related with the MioPliocene terrace (some of them found in places very close to each other) by means of a post-Early Pliocene uplift at variable rates in different localities.

Radtke (1985) used U-series and electron spin resonance to date seven samples, collected from marine

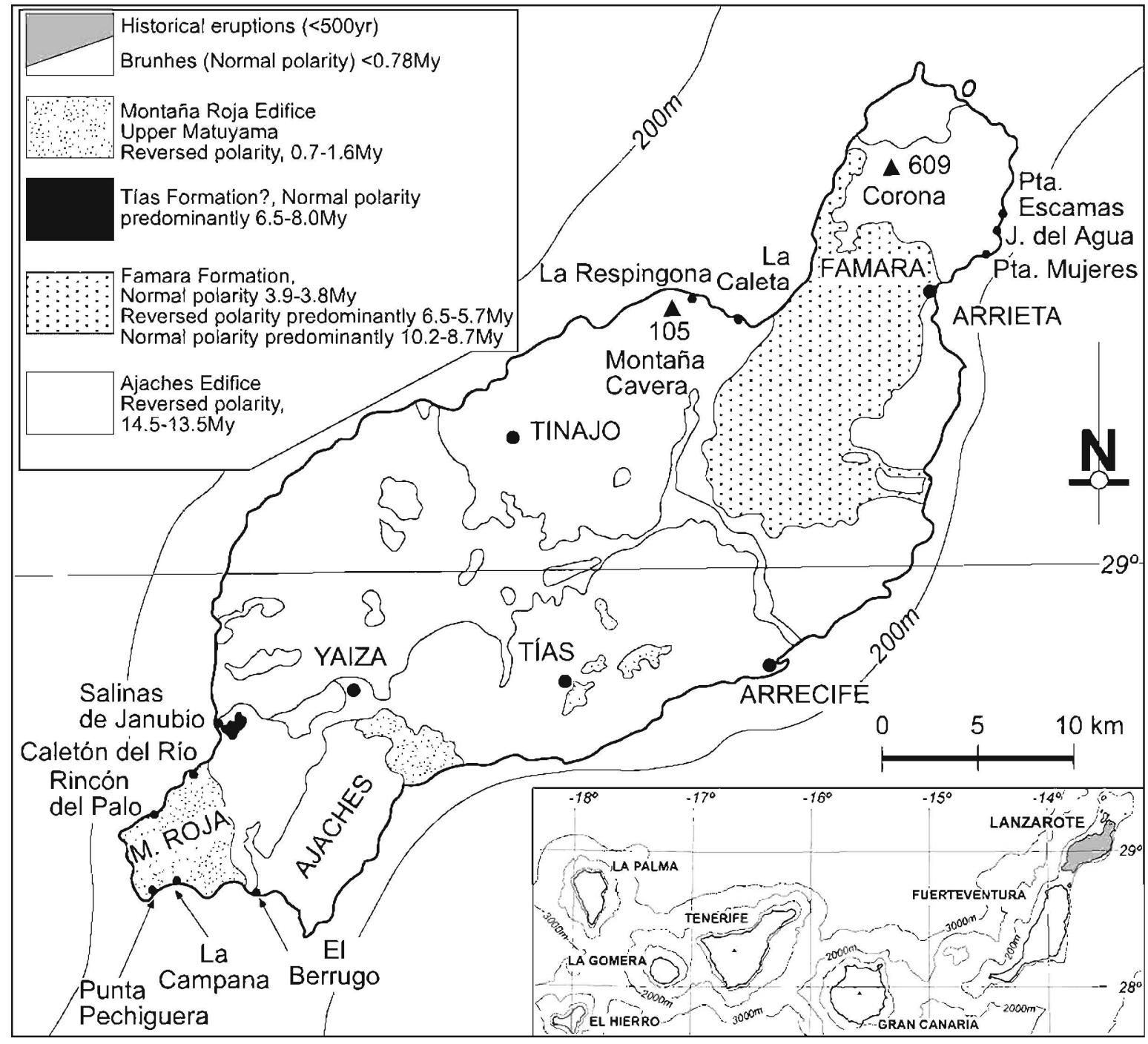

Fig. 2. Magnetic polarity map of Lanzarote Island, simplified from Carracedo and Rodríguez-Badiola (1993), and localities cited in the text. 


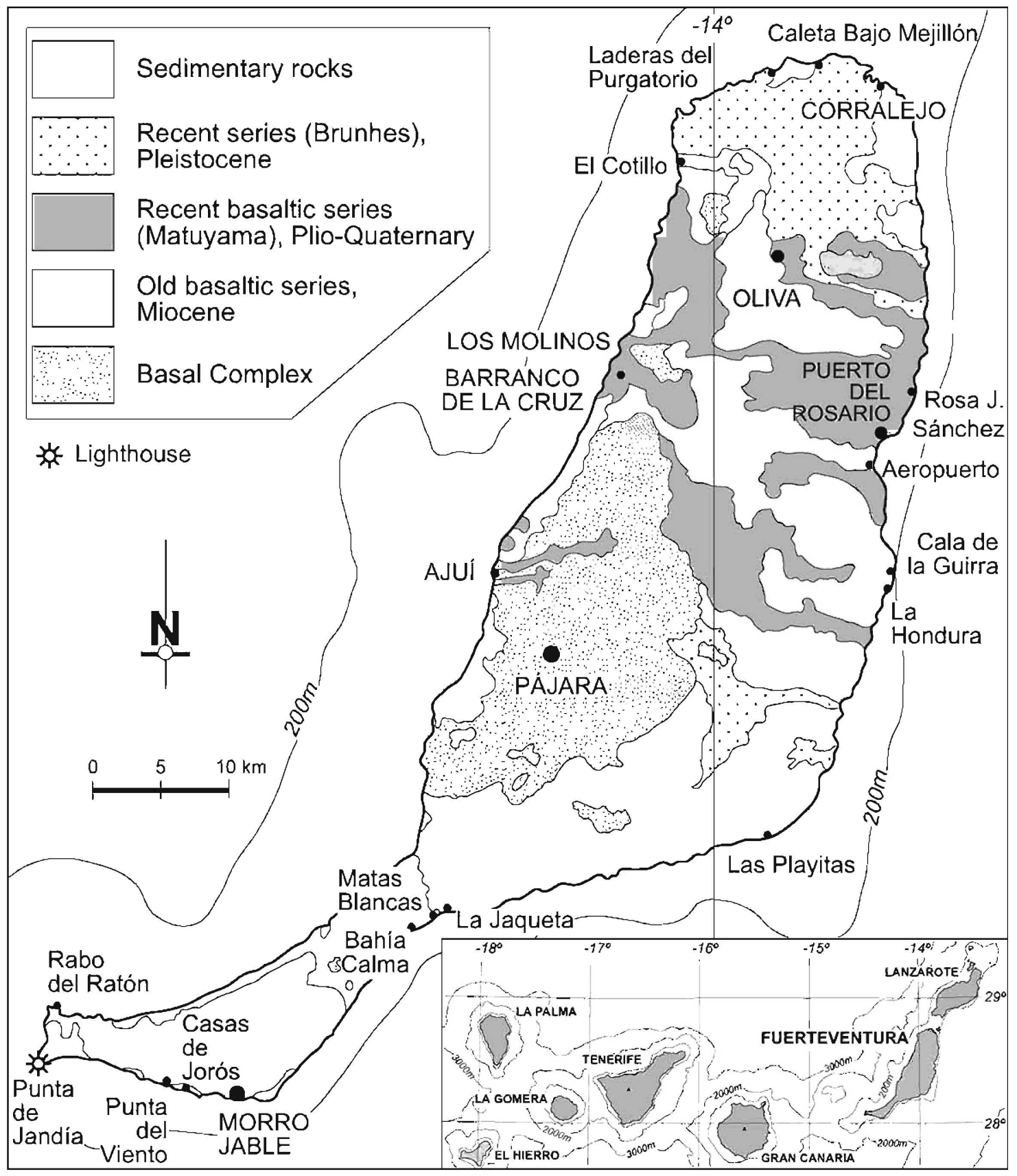

Fig. 3. Geological map of Fuerteventura Island, synthesized from Fuster and Carracedo (1979) and Ancochea et al. (1996), and localities cited in the text.

terraces bearing $S$. bubonius, at elevations +2 to $+4 \mathrm{~m}$ in Fuerteventura. He obtained ages around $\sim 125 \mathrm{ka}$ (5e) and concluded that the low elevations suggest tectonic stability of the island since Late Pleistocene.

Zazo et al. (1997) used morphosedimentary and geomorphological analysis together with a few U-series and ${ }^{14} \mathrm{C}$ dating to propose changes of sea level during MIS 5e and MIS 1. In short, Zazo et al. (1999, 2000a, b) suggested that there are preserved Quaternary, but preLast Interglacial, marine terraces in Lanzarote and Fuerteventura, characterized by a warm fauna. Thus, there is still controversy about the number of marine levels and their chronology and, as a consequence, about the tectonic stability or instability of these islands since the Pleistocene.

The present study was undertaken with the objective of reconciling the findings of the papers published in the 1960 s with those published in more recent times. It is based on a careful mapping survey, morphosedimentary and geomorphological studies, and comprehensive dating. Its expected output includes best estimates for Pleistocene movements as well as on more recent trends. 
The setting of a chronology of raised marine terraces beyond ${ }^{14} \mathrm{C}$ timescale limits always represents a major issue. In the present case, a few marine units post-date lava flows. In such cases, there have been attempts at dating the underlying volcanic units by the $\mathrm{K} / \mathrm{Ar}$ method, or at setting paleomagnetic constraints on their age. However, in most cases, the only material suitable for the setting of a chronology were the fossil mollusc shells from the marine units themselves. Two methods are currently used for the setting of ages in such material, both with uneven success: U-series measurements and amino acid, notably allo/isoleucine, measurements. These methods often allow unequivocal assignment of marine terraces to a given high sea-level of MIS 17 , but more rarely provide reliable chronological information for various reasons. Indeed, seriate measurements of U-isotopes in modern and fossil mollusc shells have shown that most of the uranium present in these shells is of diagenetic origin (Kaufman et al., 1996; Labonne and Hillaire-Marcel, 2000). As a consequence, U-series data from such material often result in the spreading of ages for any given terrace in response to variable U-uptake fluxes through the shells (e.g., Zazo et al., 1999). However, U-series ages from such fossils may provide good estimates for the true age of the embedding sediments in a few favourable diagenetic situations. This is the case when $U$ is uptaken during an early and short diagenetic episode, followed by a relatively efficient closure of the radioactive system (i.e., with negligible late diagenetic Ufluxes through the shells). Three sets of diagenetic settings seem favourable. They include: (i) fast cementation of littoral deposits such as beach rocks (HillaireMarcel et al., 1996), (ii) arid post-depositional conditions with negligible dissolved U-circulation through the deposits (e.g., Ortlieb et al., 1992), and (iii) low redox conditions with reduced U-fluxes in sediment pore water (e.g., Fontes et al., 1996). In the present case, the aridity of the Eastern Canary Islands and the strong cementation of most marine terraces seem to fulfil two of these conditions, suggesting therefore that U-series measurements on fossil mollusc should provide here a suitable approach for the dating of the most recent marine units.

Total amino acid (TAA) contents and epimerization rates of allo/isoleucine $(A / I)$ can be used first as an index of preservation of the organic matrix of the shell (e.g., Mitterer, 1993). Generally, TAA contents decrease rapidly as a function of the age of the fossil shell (e.g., Hare and Abelson, 1968) and thus provide constraints on the relative ages of marine units in a given raised sequence. However, D-alloisoleucine/L-isoleucine ratios generally provide a much better geochronological tool, although the thermal history of the fossils, as well as their geochemical settings, may have a strong incidence on these ratios (e.g., Wehmiller and Miller, 1990; Leonard and Wehmiller, 1992). In the present case,
A/I ratios have essentially been used as a means to distinguish Holocene vs. Last Interglacial deposits, and to ensure that the fossils used for U-series measurements were not reworked from older units.

\section{Materials and methods}

\subsection{Air photo and field investigations}

The first step was detailed geomorphological mapping of marine and terrestrial deposits, and the volcanic rocks related with them, based on air photographs scaled $1: 25,000$ (year 1988). In areas with more complete stratigraphical sequences but small outcrops, we used photographs 1:5000 (shot in 1989). Maps were always carefully checked in the field. Before sampling a given morphosedimentary unit we carried out facies analysis of sedimentary units focused to determine beach (shoreface foreshore backshore) and shallow-marine zones, and the accompanying terrestrial (alluvial) to transitional (fan-deltaic) facies. This is essential as a means of fixing the present topographic elevation of a given marine layer with respect to the present-day datum, and also to analyse any possible record of eustatic oscillations inside a given individual morphologic terrace. In this paper, topographic elevations are referred to the high tide level (Datum $=0 \mathrm{~m}$ ). The mean annual average tidal range in Canary Islands is $\sim 3 \mathrm{~m}$.

We call the event which produced the marine deposits accumulated during an Interglacial or marine isotopic stages/substages (MIS) a "marine Episode". Generally, these Episodes coincide with morphological terraces, but some Holocene deposits are beach ridges. Episodes have been numbered following stratigraphic order I (the oldest) through XII (the youngest). Some Episodes include several units that record minor eustatic oscillations, sometimes probably related to different highstands, and they have been separated (for instance: XI, XI.1, XI.2, etc.)

\subsection{Paleontological studies}

Paleontological studies included taphonomy (fragmentation, abrasion, bioerosion, and bioencrustation), and paleoecology of macrofauna. As this work is not specifically paleontological research and the recollected material was relatively abundant, we have included in the figures the material collected by us that imply conditions warmer than the present, such as $O$. virleti, $N$. emiliana, Astraea rugosa, Semicassis linga and Strombus. Considering the problems concerning the univocal determination of Strombus, we assign the name $S$. bubonius for specimens contained in marine deposits of the Last Interglacial, using the genus name Strombus 
(S. cf. coronatus $S$. cf. bubonius) for shells collected from older marine deposits.

The results of U-series and $\mathrm{A} / \mathrm{I}$ measurements on mollusc shells pertaining to genus are known to be very variable due to differences in composition and internal structure of shells. For this reason, whenever it is possible, we specify genus and species.

\subsection{Paleomagnetic analysis}

We sampled the volcanic Montaña Roja and Femés Formations in the southwestern Lanzarote Island, for paleomagnetic analysis and $\mathrm{K} / \mathrm{Ar}$ measurements in the same localities, with some additional samples (Fig. 4, Table 1A and B). Geographic coordinates were fixed using a portable GPS referred to ellipsoid World Geodetic System (WGS) 84. The cores were taken using a portable gasoline-powered drill from sites, and oriented with a sun compass.

The Natural Remanent Magnetization (NRM) was measured with a JR4 spinner magnetometer. All samples were submitted to a stepwise thermal demagnetization between $50^{\circ} \mathrm{C}$ and $600^{\circ} \mathrm{C}$ to isolate the main NRM component. In each step the magnetic susceptibility was measured with a Kappabridge KLY2 device. The results are presented in Table 1A.

\section{4. $\mathrm{K} / \mathrm{Ar}$ measurements}

The volcanic Ajaches and Femés Formations have been sampled in the south-western Lanzarote Island (Fig. 4) in localities where they are directly related to marine deposits (samples $77 \mathrm{~K}$ and $77 \mathrm{M}$, Montaña Roja Formation, sample $77 \mathrm{Q}$ in Femés Formation, Table 1). The only exception is the control sample $77 \mathrm{~L}$ collected from the Montaña Roja mountain.

Precise dating of young volcanic rocks by the potassium argon method is limited by two factors: the relatively long half time of ${ }^{40} \mathrm{~K}$ and low abundance of $\mathrm{K}$ in basalts. This implies that only small amounts of radiogenic ${ }^{40} \mathrm{Ar}$ accumulate in the rocks over periods of $10^{4} 10^{6} \mathrm{yr}$. Moreover, argon is a major component of the atmosphere which equilibrates with the lavas as they cooled. Hence, in the total argon extracted from young basaltic samples, the proportion of radiogenic argon is very low compared to air argon, and the precision of the dating depends essentially on an accurate correction for the atmospheric contamination.

Cassignol and Gillot (1982) and Gillot and Cornette (1986) have discussed the factors which may limit the precise measurements of small amounts of radiogenic argon within a total ${ }^{40} \mathrm{Ar}$ signal composed principally of atmospheric argon that contributes both from the mineral sample and from the extraction system. It consists of a direct comparison between sample argon and atmosphere argon under rigorous identical condi- tions of measurement in the mass spectrometer to detect the smallest departure between isotopic ratios for sample argon and atmosphere argon. Another specificity of the Cassignol and Gillot technique (1982) is the calibration of the electric signal detected for ${ }^{40} \mathrm{Ar}$ ion beam for comparison with the signal obtained for a volumetrically known amount of atmosphere argon (Gillot and Cornette, 1986). This allows dating using only the natural isotopes of argon, without the addition of ${ }^{38} \mathrm{Ar}$ spike or neutron activation to produce ${ }^{39} \mathrm{Ar}$, thus limiting the correction factors and ensuring higher precision. Nevertheless, the precision and accuracy depends primarily on the sample selection and preparation. From careful thin section and petrographic observation, only fresh and massive, zeolite-free basaltic samples have been selected for age measurements. The $\mathrm{K}$ Ar measurements have been done on the pure selected groundmass, according to the techniques described by Gillot and Cornette (1986). The groundmass is the phase which concentrates the potassium in basaltic lavas. This (i) reduces atmospheric argon contamination, (ii) avoids the effects of extraneous radiogenic ${ }^{40} \mathrm{Ar}$ inheritance from pheno- and xenocrystals, and (iii) ensures the homogeneity of the grain aliquots. Samples were crushed and sieved to a 250 $400 \mu \mathrm{m}$ size fraction and subjected to $1 \mathrm{~h}$ of ultrasonic cleaning in a $20 \%$ nitric acid solution, followed by complete rinsing and drying. After that, the groundmass was concentrated by means of heavy liquids (methylene iodide diluted in acetone) and magnetic separations, in order to eliminate early crystallizing minerals (plagioclase, olivine and pyroxene pheno- or xenocrystals). This process strongly limits the influence of possible inherited Ar. The results are reported in Table 1A. The International Conventional Constants (Steiger and Jaeger, 1977) have been used for the age calculation.

\subsection{U-series measurements}

$\mathrm{U}$-series analyses were generally performed on a second aliquot of the samples used for allo isoleucine measurements. Analytical procedures for $\mathrm{U}$ and $\mathrm{Th}$ separation followed Edwards et al. (1987), with a modified two-stage extraction with $6 \mathrm{~N} \mathrm{HCl}$ and $7 \mathrm{~N}$ $\mathrm{HNO}_{3}$ to increase the yield of $\mathrm{U}$ (see Hillaire-Marcel et al., 1996, for more details). Measurements were made on a VG-Sector ${ }^{\mathrm{TM}}$ thermal ionization mass spectrometer equipped with an electrostatic filter and an ion-counting device. The overall analytical reproducibility as estimated from replicate measurements of standards, is usually better than $\pm 0.5 \%\left( \pm 2 \sigma_{e}\right)$ for $\mathbf{U}$ and $\mathrm{Th}$ concentrations as well as for ${ }^{234} \mathrm{U} /{ }^{238} \mathrm{U}$ and ${ }^{230} \mathrm{Th} /{ }^{234} \mathrm{U}$ ratio determinations. Results are presented in Table 2. 


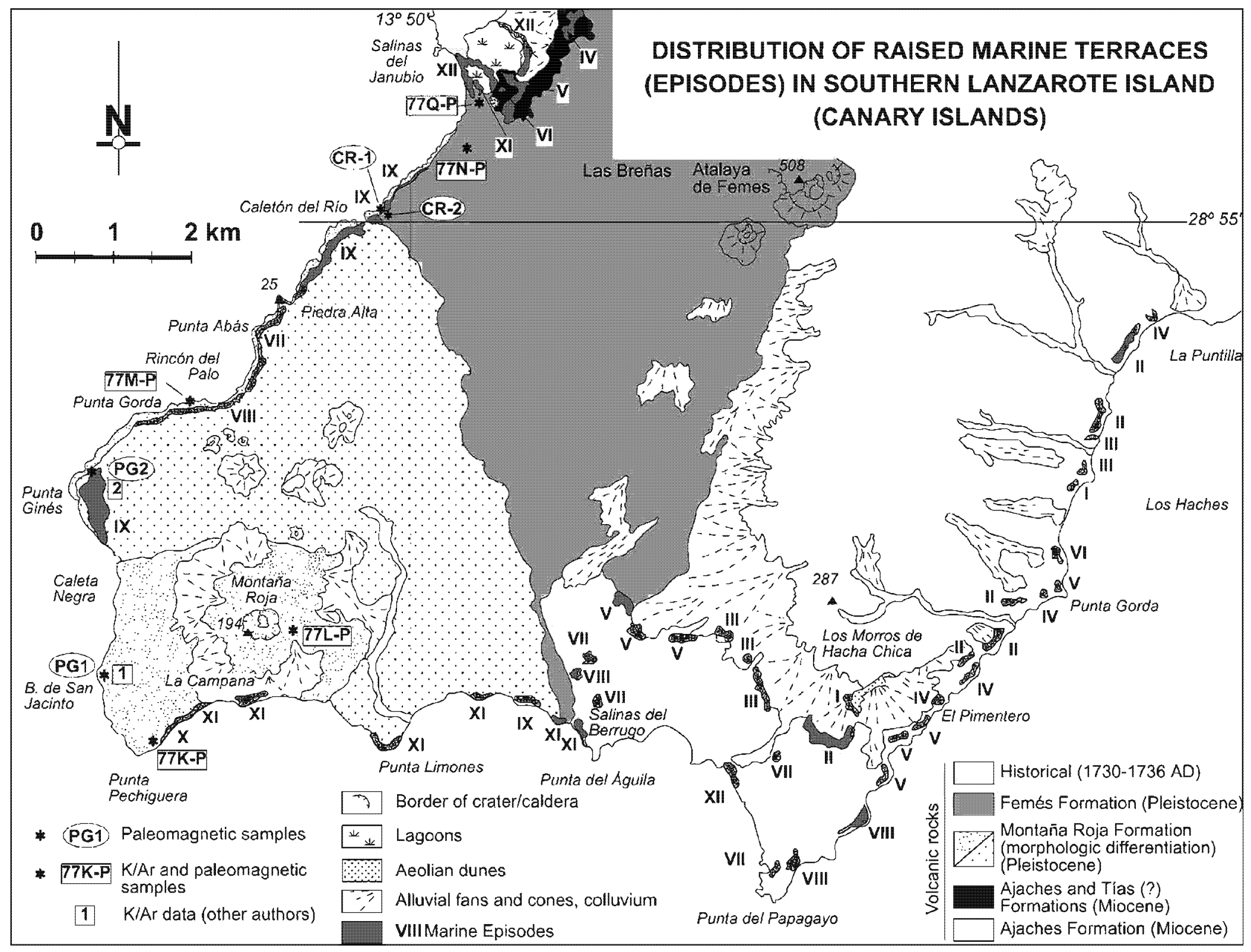

Fig. 4. Geological map of southern Lanzarote Island and distribution of raised marine Episodes. In ascending stratigraphic order, I: $65-70 \mathrm{~m}$, II: $50-55 \mathrm{~m}$, III: 40-45 m, IV: $35-40 \mathrm{~m}$, V: $25-30 \mathrm{~m}$, VI: 20-25 m, VII: 17-18 m, VIII: 12-14 m, LX: 8-10m, X: $1 \mathrm{~m}$, XI: 0-1 m, XII: 0.5 m (All values above present mean sea level, asl. K/Ar samples from previous authors: [ Coello et al. (1992), 国: Meco and Stearns (1981). 
Table 1

(a) $\mathrm{K} / \mathrm{Ar}$ measurements, and (b) paleomagnetic measurements in South-western Lanzarote. (1): Referred to WGS (World Geodetic System) 84 datum. (2) Number of samples per site. (3) Precision parameter, (4) Radius of circle of confidence at $95 \%$ significance level

\begin{tabular}{|c|c|c|c|c|c|c|c|c|c|}
\hline $\begin{array}{l}\text { Sample } \\
\text { number }\end{array}$ & Locality & $\begin{array}{l}\text { Lat. N } \\
\text { (1) }\end{array}$ & $\begin{array}{l}\text { Long-W } \\
\text { (1) }\end{array}$ & $\mathrm{K} \%$ & $\operatorname{Rad} .{ }^{40} \mathrm{Ar} \%$ & $\begin{array}{l}\text { Rad. }{ }^{40} \mathrm{Ar} \\
\text { atoms } \times \mathrm{g}^{-1}\end{array}$ & $\mathrm{~K} / \mathrm{Ar}$ age $\mathrm{Myr} \pm 2$ sigma & & \\
\hline \multicolumn{10}{|c|}{ (a) $K / A r$ measurements } \\
\hline $77 \mathrm{~L}$ & Montaña Roja & $28^{\circ} 51^{\prime} 56^{\prime \prime}$ & $13^{\circ} 50^{\prime} 55^{\prime \prime}$ & 1.063 & 11.7 & $1.452 \mathrm{E}+12$ & $1.31 \pm 0.03$ & & \\
\hline $77 \mathrm{M}$ & Rincón del Palo & $28^{\circ} 53^{\prime} 43^{\prime \prime}$ & $13^{\circ} 51^{\prime} 40^{\prime \prime}$ & 1.231 & 30.9 & $1.613 E+12$ & $1.25 \pm 0.02$ & & \\
\hline $77 Q$ & Salinas de Janubio & $28^{\circ} 55^{\prime} 53^{\prime \prime}$ & $13^{\circ} 49^{\prime} 43^{\prime \prime}$ & 0.634 & 1.3 & $1.059 \mathrm{E}+11$ & $0.16 \pm 0.02$ & & \\
\hline \multicolumn{10}{|c|}{ (b) Paleomagnetic measurements } \\
\hline $77 \mathrm{~K}-\mathrm{P}$ & Punta Pechiguera & $28^{\circ} 51^{\prime} 34^{\prime \prime}$ & $13^{\circ} 51^{\prime} 55^{\prime \prime}$ & 16 & 197.4 & -37.8 & 1.3 & 820 & Montaña Roja \\
\hline $77 \mathrm{~L}-\mathrm{P}$ & Montaña Roja & $28^{\circ} 51^{\prime} 56^{\prime \prime}$ & $13^{\circ} 50^{\prime} 55^{\prime \prime}$ & 14 & 195.5 & -35.4 & 1.2 & 1016 & Montaña Roja \\
\hline $77 \mathrm{M}-\mathrm{P}$ & Rincón del Palo & $28^{\circ} 53^{\prime} 43^{\prime \prime}$ & $13^{\circ} 51^{\prime} 40^{\prime \prime}$ & 7 & 197.8 & -36.5 & 2.3 & 686 & Montaña Roja \\
\hline PG-1 & Bajo de San Jacinto & $28^{\circ} 51^{\prime} 40^{\prime \prime}$ & $13^{\circ} 52^{\prime} 35^{\prime \prime}$ & 4 & 194.8 & -39.5 & 3.4 & 755 & Montaña Roja \\
\hline
\end{tabular}

\subsection{AlI measurements}

After mechanical cleaning with a brush, shell samples were crushed in an agathe mortar. TAA contents and A/I ratios were determined on aliquots using highpressure liquid chromatography. The shell carbonates were dissolved with $6 \mathrm{~N} \mathrm{HCl}$ and spiked with the synthetic amino acid norleucine. Samples were then hydrolysed by oven heating at $110^{\circ} \mathrm{C}$ for $22 \mathrm{~h}$. An automated cation exchange HPLC and post-column derivitization by ophthaldialdehyde for fluorescence detection were used. Individual amino acid concentrations were calculated by comparison with the peak area of the norleucine internal standard. For D-alloisoleucine/ L-isoleucine ratio measurements, the analytical uncertainty is better than $5 \%( \pm 1 \sigma$ relative $)$ when determined on replicate measurements of standard samples, but the error may be as high as $\pm 10 \%$ for replicate measurements on fossil molluscs. Results are reported in Table 3.

\section{7. ${ }^{14} \mathrm{C}$ measurements}

A few analyses of ${ }^{14} \mathrm{C}$ were carried out in samples from beach rocks of the intertidal zone. Ages cited in the text are calibrated using version 3.0 of the CALIB Program software (Stuiver and Reimer, 1993).

\section{Physiographical and geological settings}

The Canarian Archipelago (Fig. 1) is a volcanically active alignment of seven islands, the easternmost of which lies $125 \mathrm{~km}$ off Cape Jubi, on the Moroccan coast. They form the western extremity of the Saharan climatic zone, with just $100 \mathrm{~mm}$ of mean annual rainfall, a typical arid condition with a mean annual temperature of $19^{\circ} \mathrm{C}$. The wind systems are dominated by alternating Atlantic westerlies and northeast trade winds, thereafter being more active between April and September. The archipelago is under the influence of Saharan winds throughout the year, but particularly in summer and autumn causing daily temperatures to surpass $40^{\circ} \mathrm{C}$ (Fuerteventura). A main climatic control is the cold Canary marine current that reduces rainfall, regulates temperatures and forms a thermal barrier with local variations of superficial seawater temperatures.

The geographic location of the archipelago, particularly the easternmost islands, between $2829^{\circ} \mathrm{N}$ and 13 $15^{\circ} \mathrm{W}$, is close to the tropic of Cancer and some $2000 \mathrm{~km}$ from the entrance of the Mediterranean Sea. For this reason the Canary Islands are a passage zone suitable for recording not only the faunal migrations between the equatorial Atlantic Ocean and the Mediterranean Sea during the Quaternary, but also the climatic changes, particularly those related to aridity/humidity parameters that reflect the latitudinal shifts of the African climatic belt separating the arid Sahara from the humid tropical zones.

The Canary Islands are located on old (Jurassic) oceanic lithosphere, close to a continental margin, and on a tectonic plate which is moving very slowly in relation to an underlying mantle hotspot (Carracedo et al., 1998). Extensive $\mathrm{K} / \mathrm{Ar}$ dating coupled to paleomagnetic analyses (Figs. 2 and 3 ) allow a good control of the subaerial volcanic history that, in the case of Lanzarote and Fuerteventura Islands began at 15.5 and 20.6 Myr respectively (Carracedo et al., 1998), with hiatuses in the eruptive activity in the early 
Table 2

U-series measurements in mollusc shells from the studied marine terraces and beach rocks. Measurements made by alpha spectrometry. The corresponding errors are given with a \pm 1 standard deviation. All other measurements were made with TIMS and results are quoted with \pm 2 standard errors. In italics, data from the calcite cementing Last interglacial deposits at Caleta del Bajo de Mejillones. Due to the abundance of detrital minerals in the corresponding samples, direct ${ }^{230} \mathrm{Th}$ calculations are biased. The isochron age provides a better estimate for the mean age of $\mathrm{U}$ incorporated during the cementation

\begin{tabular}{|c|c|c|c|c|c|c|c|c|c|}
\hline $\begin{array}{l}\text { Field number } \\
\text { locality }\end{array}$ & $\begin{array}{l}\text { Alt } \\
\text { (m) }\end{array}$ & Taxa & $\begin{array}{l}\mathrm{U}(\mathrm{ppm}) \\
\pm 2 \sigma \mathrm{e}\end{array}$ & $\begin{array}{l}\text { Th (ppb) } \\
\pm 2 \sigma \mathrm{e}\end{array}$ & $\begin{array}{l}{ }^{234} \mathrm{U} /{ }^{238} \mathrm{U} \\
\pm 2 \sigma \mathrm{e}\end{array}$ & $\begin{array}{l}{ }^{230} \mathrm{Th} /{ }^{234} \\
\mathrm{U} \pm 2 \sigma \mathrm{e}\end{array}$ & $\begin{array}{l}{ }^{230} \mathrm{Th} \text { age }(\mathrm{ka}) \\
\pm 2 \sigma \mathrm{e}\end{array}$ & $\begin{array}{l}{ }^{14} \mathrm{C} \text { Age } \\
(\mathrm{ka}) \\
\pm 1 \sigma \mathrm{e}\end{array}$ & $\begin{array}{l}\text { Marine } \\
\text { Episode } \\
\text { (field } \\
\text { data) }\end{array}$ \\
\hline
\end{tabular}

\section{Lanzarote}

La Caleta

LZ92-35

LZ92-36

LZ92-37

0 Not.det.

0.5 Not.det.

0.8 (Crust)

$0.460 \pm 0.001$

$0.471 \pm 0.003$

$0.656 \pm 0.002$

$4.380 \pm 0.014$

$0.192 \pm 0.001$

$202.27 \pm 3.130$

$1.132 \pm 0.008$

$1.095 \pm 0.021$

$1.183+0.007$

$0.777 \pm 0.009$

$0.706 \pm 0.015$

$0.345+0.046$

$155.0 \pm 4.4$

$129.6 \pm 6.0$

$45.4 \pm 7.8$

El Berrugo

LZ92-47

LZ92-48

LZ92-49

LZ98-50

$$
\begin{array}{rr}
-0.5 & \text { Patella } \\
1.5 & \text { Patella } \\
1.4 & \text { Patella } \\
1.7 & \text { Patella }
\end{array}
$$

$0.317 \pm 0.001$

$0.370 \pm 0.002$

$0.488 \pm 0.002$

$0.028 \pm 0.001$

$1.151 \pm 0.005$

$0.101 \pm 0.001$

$0.202 \pm 0.001$

$1.187 \pm 0.004$

$1.253 \pm 0.007$

$1.154 \pm 0.012$

$1.158 \pm 0.007$

$1.140 \pm 0.005$

$0.630 \pm 0.005$

$0.681 \pm 0.007$

$0.705 \pm 0.005$

$0.733 \pm 0.009$

$103.4 \pm 1.3$

$119.6+2.6$

$127.1 \pm 1.8$

$137.5 \pm 3.4$

La Campana

LZ92-51

LZ92-52

LZ92-53

\section{-0.5 Patella}

0.8 Patella

$0.213 \pm 0.001$

$0.462 \pm 0.002$

$3.953 \pm 0.020$

$5.528 \pm 0.028$

0.8 Not.det.

$0.791 \pm 0.003$

$4.419 \pm 0.024$

$1.193 \pm 0.010$

$1.168+0.012$

$0.577 \pm 0.009$

$1.131 \pm 0.011$

$0.673 \pm 0.009$

$0.658 \pm 0.008$

Pta. Respingona

LZ94-2

LZ94-4

0.8 Patella

0.5 Patella

$0.388 \pm 0.001$

$0.351 \pm 0.001$

$167.72 \pm 1.185$

$29.124 \pm 0.110$

$1.262 \pm 0.006$

$1.156 \pm 0.006$

$1.031 \pm 0.013$

$0.669 \pm 0.008$

Punta Pechiguera

LZ92-54

LZ92-55

LZ98-20

LZ98-21

LZ98-22

Jameos del Agua

LZ92-31

-0.5 Not.det.

1 Not.det.

$0.030 \pm 0.001$

$0.310 \pm 0.001$

$0.295 \pm 0.001$

0.5 Patella

-0.5 Not.det.

$0.486 \pm 0.002$

$0.496 \pm 0.002$

1 Patella

$0.367 \pm 0.002$

$0.406 \pm 0.003$

$0.319 \pm 0.001$

$27.389 \pm 0.108$

$0.340 \pm 0.002$

$1.066 \pm 0.013$

$1.399 \pm 0.007$

$1.158 \pm 0.010$

$1.055 \pm 0.017$

$1.110 \pm 0.007$

$0.986 \pm 0.018$

$1.084 \pm 0.007$

$1.007 \pm 0.009$

$1.020 \pm 0.022$

$0.689 \pm 0.007$

$90.7 \pm 2.2$

$117.0 \pm 3.2$

$113.1 \pm 2.7$

$355 \pm 35$

$116.1 \pm 2.6$

$323 \pm 53$

$421 \pm 30$

$355 \pm 30$

$[\infty]$

$123.0 \pm 2.5$

0.5 Not.det.
0.5 Not.det.

0.5 Not.det.

1.5 Strombus $0.377 \pm 0.010$

1 Strombus

$1.217 \pm 0.003$

$0.351 \pm 0.001$

$1.215 \pm 0.009$

$0.837 \pm 0.007$

$0.044 \pm 0.001$

$1.224 \pm 0.011$

$0.631 \pm 0.007$

$178.3 \pm 4.4$

$104.0 \pm 2.1$

La Jaqueta

FV92-3

1 Conus

Las Playitas

FV92-15

FV92-18

El Cotillo

FV92-24

FV92-25

El Cotillo (well)

FV92-28

C. La Guirra

FV94-1

FV94-3

La Hondura

FV94-13

FV94-14

\section{Patella}

0.8 Patella

$0.273 \pm 0.001$

$0.106 \pm 0.001$

$1.515 \pm 0.006$

$0.702 \pm 0.002$

$1.207 \pm 0.009$

$1.162 \pm 0.008$

$0.742 \pm 0.009$

$0.004 \pm 0.001$

$0.189 \pm 0.001$

$0.599 \pm 0.008$

$1.023 \pm 0.019$

0.1 Patella

$0.231 \pm 0.001$

$0.893 \pm 0.005$

$1.081 \pm 0.010$

$0.977 \pm 0.024$

$0.887 \pm 0.013$

$0.717 \pm 0.004$

$2.951 \pm 0.014$

$1.156 \pm 0.013$

$0.728 \pm 0.010$

$135.3 \pm 4.3$

$0.105 \pm 0.001$

$5.473 \pm 0.025$

$1.122 \pm 0.008$

$1.149+0.006$

$0.675 \pm 0.019$

$0.695 \pm 0.009$

$118.6 \pm 6.2$

$124.3 \pm 3.2$

0.5 Patella

0 Patella
$0.091 \pm 0.001$

$0.155 \pm 0.001$
$2.877 \pm 0.007$

$2.256 \pm 0.007$
$1.161 \pm 0.007$

$1.143 \pm 0.005$
$0.019 \pm 0.001$ $0.023 \pm 0.002$
XI.2

XI.1

XI.1

XI. 1

XI. 2

XI.2

XI.1

XI. 2

XI. 2

XI.1

XI.1

$\mathrm{X}$

$\mathrm{X}$

$\mathrm{X}$

$\mathrm{X}$

$5265 \pm 130 \quad$ XII

$5630 \pm 155 \quad$ XII

$5815 \pm 130$

XII

XI.1

XI.2

$2085 \pm 140$

XI

XII

$\mathrm{X}$ ?

$\mathrm{X}$ ?

XI

XI.1

XI.2 
Table 2 (continued)

\begin{tabular}{|c|c|c|c|c|c|c|c|c|c|}
\hline $\begin{array}{l}\text { Field number } \\
\text { locality }\end{array}$ & $\begin{array}{l}\text { Alt } \\
\text { (m) }\end{array}$ & Taxa & $\begin{array}{l}U \text { (ppm) } \\
\pm 2 \sigma \mathrm{e}\end{array}$ & $\begin{array}{l}\text { Th (ppb) } \\
\pm 2 \sigma \mathrm{e}\end{array}$ & $\begin{array}{l}{ }^{234} \mathrm{U}^{238} \mathrm{U} \\
\pm 2 \sigma \mathrm{e}\end{array}$ & $\begin{array}{l}{ }^{230} \mathrm{Th} /{ }^{234} \\
\mathrm{U} \pm 2 \sigma \mathrm{e}\end{array}$ & $\begin{array}{l}{ }^{230} \mathrm{Th} \text { age }(\mathrm{ka}) \\
\pm 2 \sigma \mathrm{e}\end{array}$ & $\begin{array}{l}{ }^{14} \mathrm{C} \text { Age } \\
(\mathrm{ka}) \\
\pm 1 \sigma \mathrm{e}\end{array}$ & $\begin{array}{l}\text { Marine } \\
\text { Episode } \\
\text { (field } \\
\text { data) }\end{array}$ \\
\hline
\end{tabular}

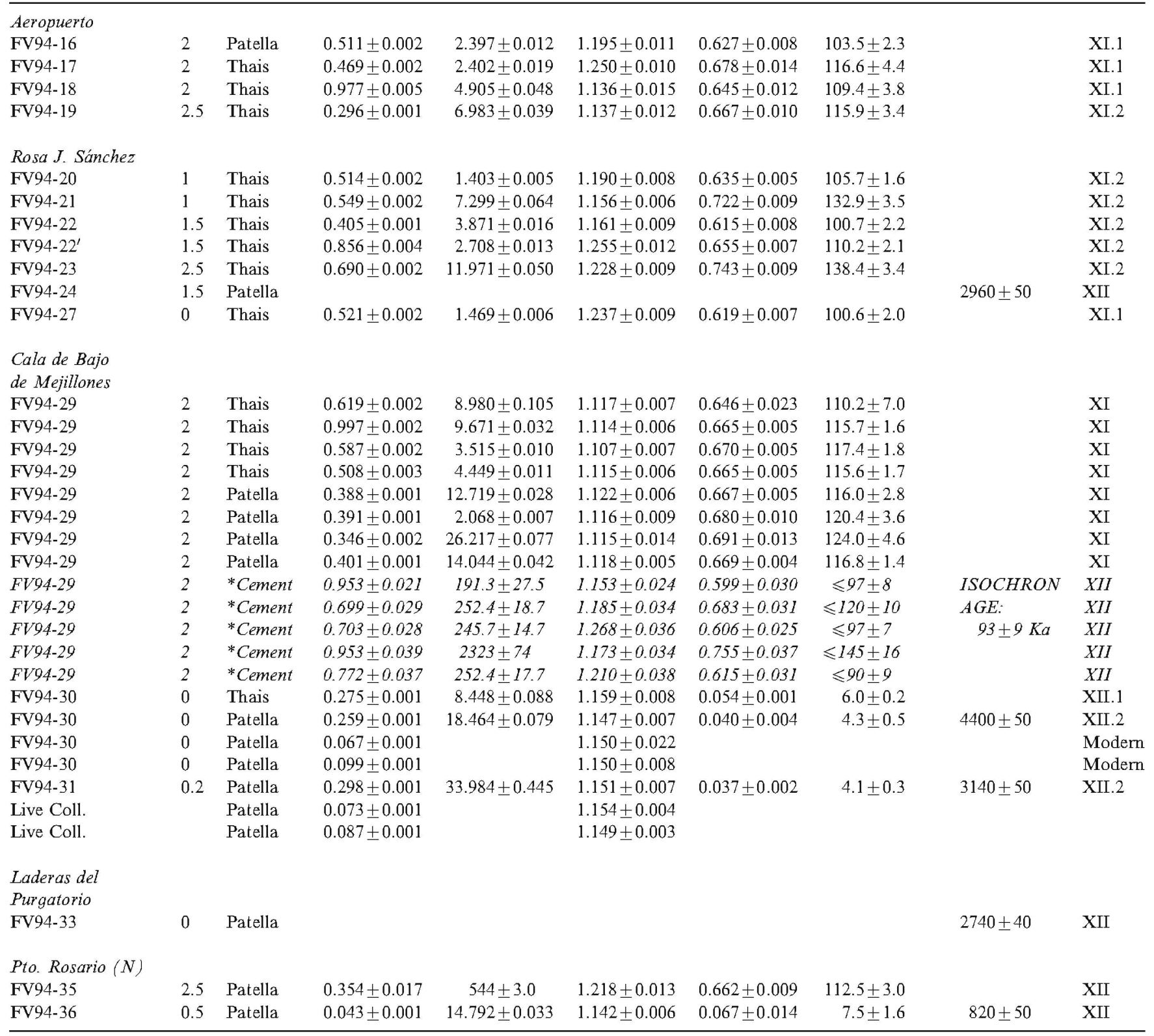

(lower-middle Miocene) emerged islands of Lanzarote and Fuerteventura.

\section{Results}

\subsection{Mapping and major stratigraphic sequences}

More than 100 sites have been studied in Fuerteventura and Lanzarote Islands. Although the marine episodes are usually poorly developed, we carried out paleontological and morphosedimentary (facies analyses and geometry of units) studies, paying particular attention to the geomorphological framework in order to establish the stratigraphic architecture (geometric and spatial relationships) of marine and terrestrial deposits and lava flows. This required detailed photo-interpretation that was later transformed into a geological map, and also the measuring of stratigraphic sections. In this paper, we present detailed maps of southern Lanzarote 
Table 3

Allo/Isolencine measurements in mollusc shells from the studied marine terraces

\begin{tabular}{|c|c|c|c|c|c|c|c|}
\hline $\begin{array}{l}\text { Field number } \\
\text { locality }\end{array}$ & $\begin{array}{l}\text { Alt } \\
(\mathrm{m})\end{array}$ & Taxa & $A / I$ & $\begin{array}{l}\text { TAA } \\
\mathrm{Pm} / \mathrm{mg}\end{array}$ & $\begin{array}{l}{ }^{230} \text { Th-age } \\
(\mathrm{Ka}) \pm 2 \sigma \mathrm{e}\end{array}$ & ${ }^{14} \mathrm{C}$-age (ka) & $\begin{array}{l}\text { Marine Episode } \\
\text { field } \\
\text { interpretation }\end{array}$ \\
\hline
\end{tabular}

\section{Lanzarote}

El Berrugo

LZ92-47

LZ92-48

LZ92-49

LZ92-50

LZ98-18

LZ98-19

-0.5
1.5
1.4
2
1.5
1.4

Patella

Patella

Patella

Patella

Patella candei

Patella candei

Patella candei

Patella aspera

Patella candei

Patella candei

Patella candei

Ostrea sp.

$\begin{array}{lr}0.89 & 4568 \\ 0.81 & 12182 \\ 0.61 & 9271 \\ 0.64 & 7683 \\ 0.71 & 4313 \\ 0.70 & 10273\end{array}$

$103.4 \pm 1.3$

$119.6 \pm 2.6$

$127.1 \pm 1.8$

$137.5 \pm 3.6$

4313
10273

Punta Pechiguera

LZ98-22

LZ98-22

LZ98-23

LZ98-23

\section{La Campana}

LZ98-24

LZ98-24

LZ98-24

LZ98-25

LZ98-25

Thais haemastoma

Patella lowei

Patella candei

Patella candei

Thais haemastoma

$\begin{array}{ll}0.78 & 1470 \\ 0.59 & 9960 \\ 0.67 & 1086\end{array}$

$355.0 \pm 30.0$

$123.0 \pm 2.5$

$\begin{array}{rr}1.56 & 6909 \\ 1.49 & 10047 \\ 1.07 & 5063\end{array}$

0.38

0.74

0.64

0.73

0.24

1116

3453

2796

6219

960

Salinas de Janubio

LZ98-30

LZ98-30

LZ98-31

LZ98-31

LZ98-32

LZ98-32

Fuerteventura

C. La Guirra

FV94-1

Pta. Hondura

FV94-14

Rosa. J. Sánchez

FV94-20

FV94-21

FV94-22'

FV94-23

C. Bajo Mejillones

FV94-29

FV94-29

FV94-29

FV94-31

Pto. Rosario

FV94-36

Aeropuerto

FV94-17

FV94-19

FV98-17
0.5

Patella

0.31

1.5

1.5

1.5

1.5

1

1

4

Patella

0.74

0.08

0.29

0.12

0.26

0.57

0.49

0.60

0.43

0.16

Thais

Patella

2

2.5

2.5
Thais

Thais

Thais haemastoma
0.47

0.41

0.96
1060

1843

746

3664

6078

5304

$118.6 \pm 6.2$

XI.1

$2.6 \pm 0.3$

$3.55 \pm 0.05$

XII

$105.7 \pm 1.6$

$132.9 \pm 3.5$

$110.2 \pm 2.1$

$138.4 \pm 3.4$

XI.2

XI. 2

XI. 2

XI. 2

$110.2 \pm 7.0$

$115.7 \pm 1.6$

$117.4 \pm 1.8$

$4.1 \pm 0.3$

$3.14 \pm 0.05$

$\mathrm{XI}$

$\mathrm{XI}$

$\mathrm{XI}$

$7.5 \pm 1.60$

$0.82 \pm 0.05$

XII

$116.6 \pm 4.4$

$115.9 \pm 3.4$

XI.2

XI.2

XI. 2 
Table 3 (continued)

\begin{tabular}{|c|c|c|c|c|c|c|}
\hline $\begin{array}{l}\text { Field number } \\
\text { locality }\end{array}$ & $\begin{array}{l}\text { Alt } \\
(\mathrm{m})\end{array}$ & Taxa & $A / I$ & $\begin{array}{l}\text { TAA } \\
\mathrm{Pm} / \mathrm{mg}\end{array}$ & $\begin{array}{l}{ }^{230} \mathrm{Th} \text {-age } \\
(\mathrm{Ka}) \pm 2 \sigma \mathrm{e}\end{array}$ & $\begin{array}{l}\text { Marine Episode } \\
\text { field } \\
\text { interpretation }\end{array}$ \\
\hline FV98-17 & 2.5 & Patella aspera & 0.63 & 11306 & & $\mathrm{XI} .2$ \\
\hline \multicolumn{7}{|c|}{ Tablero de Jorós } \\
\hline FV98-1 & 61 & Ostrea virleti & 0.86 & 2998 & & I \\
\hline FV98-1 & 61 & Thais haemastoma & 1.06 & 2394 & & I \\
\hline FV98-2 & 40 & Ostrea virleti & 1.21 & 4350 & & IV \\
\hline FV98-3 & 50 & Ostrea virleti & 0.56 & 4415 & & III \\
\hline FV98-4 & 27.5 & Ostrea virleti & 0.21 & 3410 & & VI \\
\hline FV $98-4$ & 27.5 & Ostrea virleti & 0.20 & 3043 & & VI \\
\hline FV $98-5$ & 1.5 & Thais haemastoma & 0.35 & 804 & & $\mathrm{XI}$ \\
\hline \multicolumn{7}{|l|}{ Rabo de Ratón } \\
\hline FV98-7 & 20 & Ostrea virleti & 1.01 & 3001 & & VII \\
\hline FV98-7 & 20 & Ostrea virleti & 1.10 & 8634 & & VII \\
\hline FV98-7 & 20 & Patella & 1.03 & 735 & & VII \\
\hline FV98-7 & 20 & Patella & 1.10 & 534 & & VII \\
\hline \multicolumn{7}{|l|}{ Bahia Calma } \\
\hline FV98-16 & 10 & Ostrea virleti & 0.77 & 5759 & & IX \\
\hline FV98-16 & 10 & Ostrea virleti & 0.96 & 3118 & & IX \\
\hline
\end{tabular}

and a sector of south-western Fuerteventura based on black and white and colour air photographs (scale 1:5000, flight 1989) that show particularly well the variable weathering of flow events.

Most of the studied marine Episodes form staircaselike arrangements of marine terraces resting upon the volcanic rocks. These terraces usually include a basal erosional surface representing a wave-cut platform, overlain by a well-cemented, fossiliferous layer of nearshore sediments, typically a few centimetres to $3 \mathrm{~m}$ thick. Usually, the marine deposits begin with a basal conglomerate (retrogradational, transgressive member) followed upwards by sandstones with pebbly layers, and seaward-inclined, low-angle, large-scale cross bedding representing foreshore facies (progradational, regressive member). In some cases these facies are covered by horizontal even-laminated sandstones interpreted as backshore facies. Some of the oldest marine Episodes that occur close to steep relief are covered by terrestrial aeolian dunes (large-scale, cross-bedded, sandstone rich in bioclasts), alluvial-fan deposits (reddish fine deposits with angular cobbles or breccias), or colluvium.

Two stacked sequences of beach rocks have been observed in some sites.

In the most complete case, a sequence of 12 marine Episodes (named I XII) was observed along the ride gorges at the southern shore of both islands. In these places, it is easy to observe the inner edge of the marine terraces and thus determine the maximum topographic elevation of the terrace in this particular place.

In Lanzarote Island, the oldest marine Episodes occur near Hacha Chica (Los Ajaches), where the marine terraces form a staircase upon Miocene volcanic rocks that reaches a topographic elevation of $70 \mathrm{~m}$ : (Episodes I: $6570 \mathrm{~m}$; II: $5055 \mathrm{~m}$; III: $4045 \mathrm{~m}$; IV: $3440 \mathrm{~m}$; V: 2530 ; VI: $2025 \mathrm{~m}$; VII: $1718 \mathrm{~m}$; VIII $1214 \mathrm{~m}$ ). There are four systems of bioclastic, well-cemented aeolian dunes associated to Episodes I, IV and V. Due to scale constraints, our map shows only the two oldest aeolian dune systems (Fig. 4) that occur stacked vertically but separated by a layer of colluvium (Fig. 5). The relief of Los Ajaches is drained by mountain creeks that feed alluvial fans. The oldest of these systems is pre-marine Episode I.

In Caletón del Río, the marine Episodes IX occurs sandwiched between the Montaña Roja (below) and Atalaya de Femés (above) lava flows (Fig. 4).

Along the southern coast (Punta Pechiguera to El Berrugo saltpans) the best developed marine Episode is XI, that occurs below $2 \mathrm{~m}$, and very often bears $S$. bubonius. It overlays the older marine Episode $\mathrm{X}$ at Punta Pechiguera (Fig. 5).

All the marine Episodes bear a rich fauna including the warm species ( $O$. virleti, $N$. emiliana, $A$. rugosa, $S$. linga, Strombus. and $S$. bubonius). The genus Patella 


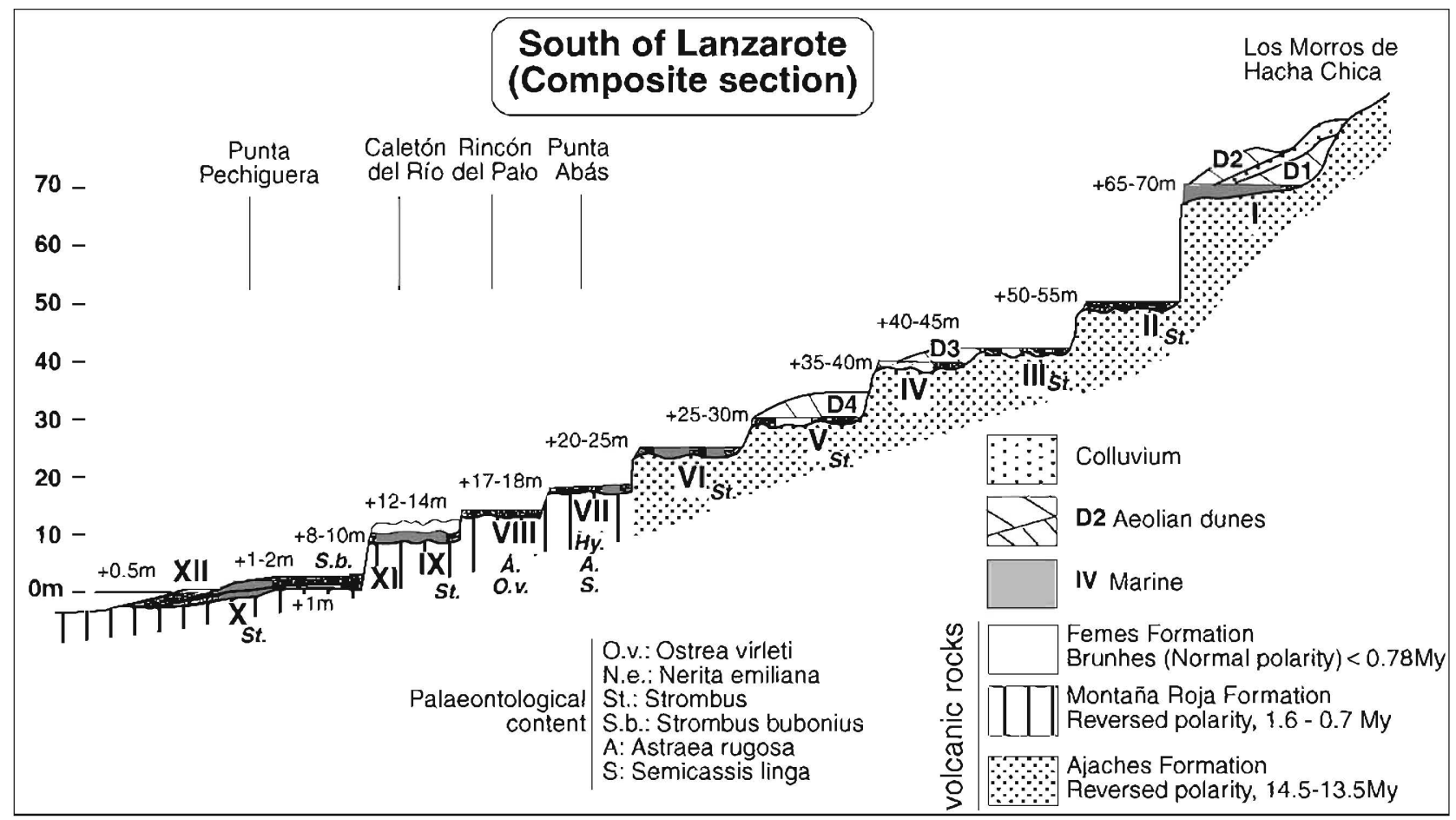

Fig. 5. Composite section showing the distribution of marine terraces I to XII in south Lanzarote Island and their relations with lava flows. The warm faunas collected from marine Episodes have been indicated (see also Fig. 4).

occurs in almost all the Episodes. In Fig. 5 we have reported only the faunas collected by us because it proved to be very difficult to locate adequately all the previously cited findings and sites.

In Fuerteventura Island, the oldest marine Episodes occur along the eastern coast and Jandia Peninsula (Fig. 3). We recognized 12 Episodes between elevations $65 \mathrm{~m}$ and present sea level (Episodes I: $6065 \mathrm{~m}$; II: $\sim 60 \mathrm{~m}$; III: 50 55 m; IV: $\sim 40 \mathrm{~m}$; V: 30 35;VI: $2025 \mathrm{~m}$; VII: $1618 \mathrm{~m}$; VIII $1214 \mathrm{~m}$; IX: $810 \mathrm{~m}$; X: $00.5 \mathrm{~m}$; XI: $04 \mathrm{~m}$; and XII: $01.5 \mathrm{~m}$ ).

The most complete sequence occurs west of Morro Jable (Fig. 3), at Valle de Jorós (Fig. 6). Nine marine terraces (Episodes I VII, XI and XII) form a staircase along a single valley and two more terraces (Episodes VIII and IX) occur in localities nearby (Fig. 7). Episode $\mathrm{X}$ has been found only in the northern coast of the island (El Cotillo).

At the base of Montaña de Jorós, the road connecting Morro Jable and the lighthouse of Jandía crosses the inclined alluvial fans covering the slopes of the mountain and a gentler slope formed by well-cemented yellowish calcarenites. Incised valleys offer good exposures of the internal structure of calcarenites: largescale, high angle cross bedding with flow directions pointing dominantly to the north. We interpret them as climbing aeolian dunes that overlie coarse-grained, fossiliferous marine deposits. Five dune systems $\left(D_{1} D_{5}\right)$ separated by rooted pedogenic horizons with rhizoconcretions are associated to marine Episodes I V. Alluvial-fan deposits accumulated in the time-span after Episode $\mathrm{V}$ and before Episode XI.

Normal faulting along $\mathrm{E} W$ lines caused onlap of Episodes I and II, and the amalgamation of Episodes II and III.

All marine terraces contain warm faunas. The most abundant species is $O$. virleti. We could not find $S$. bubonius in Episode XI in this particular site, but it occurs in deposits laterally equivalent that crop out close by.

As a conclusion, comparison of the Major Sequences in Lanzarote and Fuerteventura Islands yields several common features: (i) Same number of marine Episodes (12 staircased terraces) at comparable elevations, (ii) Presence of warm faunas in all Episodes except in the youngest Episode XII (Holocene). The faunal association is characterized by Strombus, $N$. emiliana, and $O$. virleti, although the last two species disappear after marine Episode IX (8 $10 \mathrm{~m}$ terrace), (iii) Large dune sequences associated to the older marine Episodes.

\subsection{KlAr age of lava flows and paleomagnetic analysis}

All samples have been collected from the volcanic Montaña Roja and Femés Formations (Table 1A and B) in Lanzarote Island (Fig. 4). The volcanic rocks of Montaña Roja are the substratum of the marine terraces (Fig. 5) of Episodes VII (17 18m, Punta Abas), VIII (12 14 m, Rincón del Palo), IX (8 $10 \mathrm{~m}$, Punta Ginés 


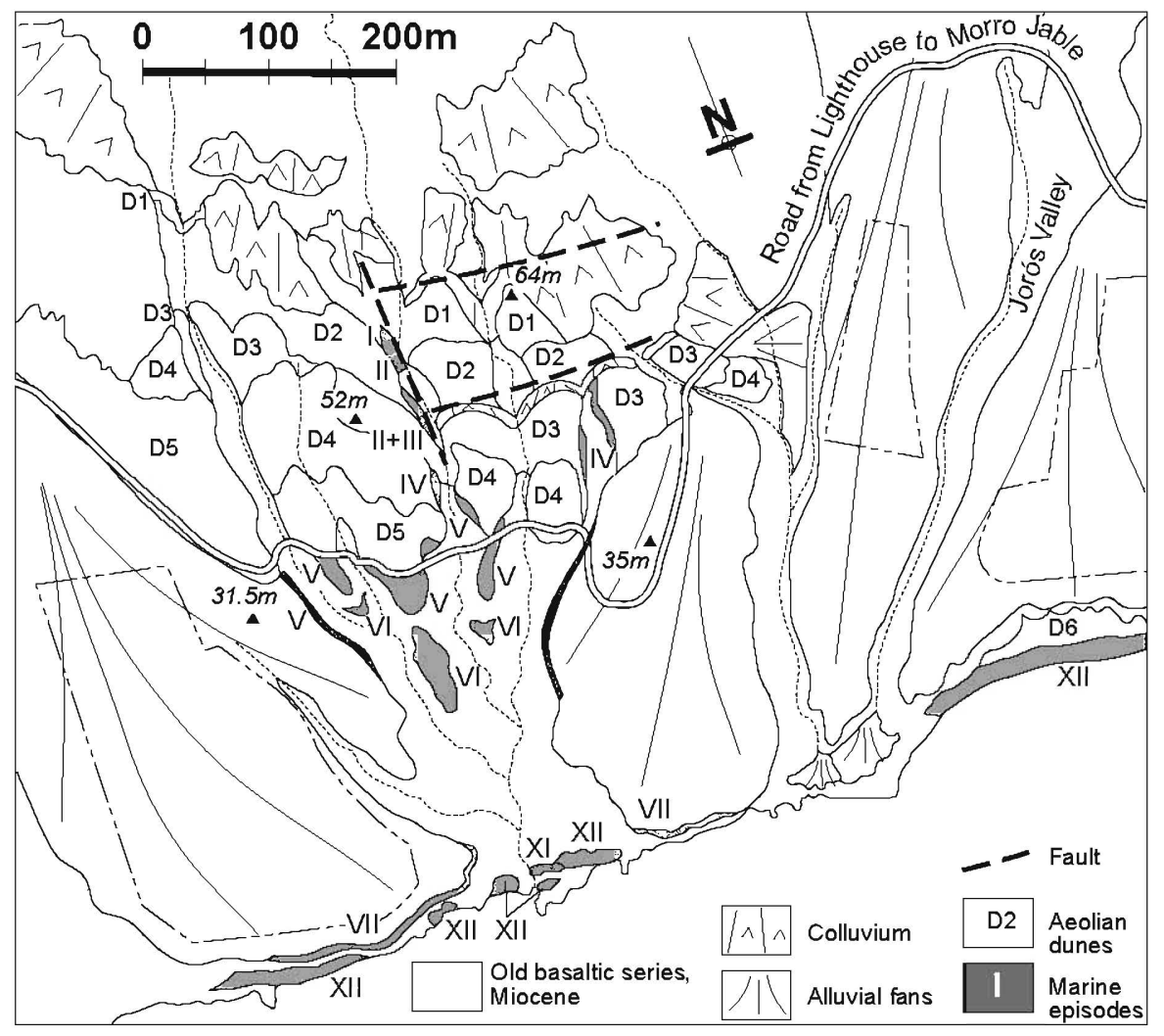

Fig. 6. Geomorphological map of terrestrial deposits and raised marine terraces (marine Episodes, in ascending stratigraphic order, I: $61 \mathrm{~m}$, II: $62 \mathrm{~m}$, III: $50 \mathrm{~m}, \mathrm{~V}: 40 \mathrm{~m}$, V: $32 \mathrm{~m}$, VI: $25 \mathrm{~m}$, VII: $16 \mathrm{~m}$, XI: $1.5 \mathrm{~m}$, XII: $0.5 \mathrm{~m}$ asl) in the Jorós valley, Jandía Peninsula, SW Fuerteventura.

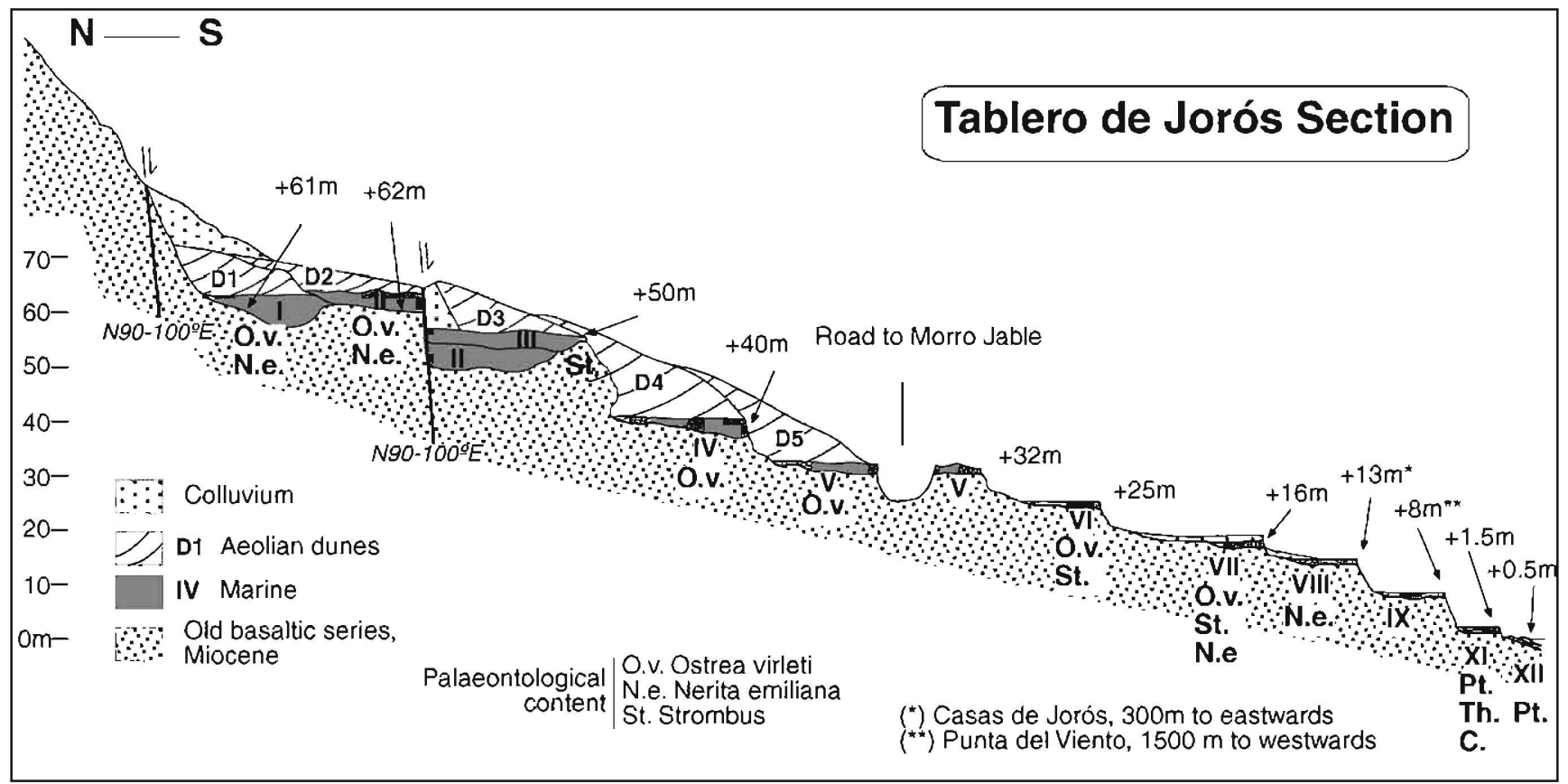

Fig. 7. Distribution of raised marine terraces (marine Episodes I to XII, with indication of the warm faunas collected by us) and terrestrial deposits, just west of Casas de Jorós (south Fuerteventura) (see also Figs. 3 and 6). 
and Caletón del Río), and X (0.5 m, Punta Pechiguera). Samples $77 \mathrm{~K}$ and $77 \mathrm{M}$ (Table $1 \mathrm{~A}$ ) were collected in the lavas just below the marine terraces of Rincón del Palo and Punta Pechiguera. A control sample (77L) was taken from the lavas at Montaña Roja peak. The three values obtained are quite comparable within the range of analytical error. A mean value of $1.2 \mathrm{Myr}$ is given for the Montaña Roja lavas. The lavas of Femés were sampled at Salinas de Janubio (77Q) immediately below the $1.5 \mathrm{~m}$ terrace of marine Episode XI (Fig. 8). The age obtained, 0.16 Myr (Table 1A), pre-dates the Last Interglacial terrace.

The magnetic polarity of all samples dated by means of $\mathrm{K} / \mathrm{Ar}$ (Fig. 4, Table 1B) is in agreement with the geomagnetic scale of polarities (Cande and Kent, 1995), with reversed polarity for Montaña Roja Formation (Matuyama, chron C1r.2r) and normal polarity for Femés (Brunhes, chron $\mathrm{C} 1 \mathrm{n}$ ).

Good clustering of ages and low dispersion of paleomagnetic directions in Montaña Roja suggest a rapid emplacement of these rocks. This hypothesis is further supported by the absence of pedogenic horizons and erosional features on the surfaces separating the various lava flows found at Rincón del Palo. High rates of vertical growth of volcanic formations in Lanzarote have been postulated in previous papers (Coello et al., 1992; Carracedo and Rodríguez-Badiola, 1993).

\subsection{U-series data}

Data are presented in Table 2 and in Figs. 8 (A D) and 9 (A, B). Modern specimens show ${ }^{230}$ Th contents below analytical threshold and $<0.1 \mathrm{ppm}$ of $\mathrm{U}$, i.e., much less than the amount expected for a marine carbonate precipitated with a water-carbonate $\mathrm{U} / \mathrm{Ca}$ partition coefficient of 1 (Gascoyne, 1992). This feature of a low "authigenic U" content in mollusc shells has been frequently reported (e.g., Hillaire-Marcel et al., 1995; Kaufman et al., 1996). This "authigenic" uranium here has an isotopic composition near 1.15 (Table 2), i.e., compatible with a marine origin for it (Chen et al., 1986). Comparatively, the samples collected in the Holocene beach-rocks show $U$ contents ranging from 0.1 to $0.3 \mathrm{ppm}$, a slightly larger scatter of ${ }^{234} \mathrm{U} /{ }^{238} \mathrm{U}$ ratios, but still with a clear mode near 1.15 (Fig. 8B). These features suggest that the "diagenetic" uranium uptaken by the shells through fossilization processes was

Fig. 8. U-series systematics in the Holocene vs. Last Interglacial molluse shell samples. Histograms of ${ }^{230} \mathrm{Th} /{ }^{234} \mathrm{U}$ (A and $\mathrm{C}$ ) and ${ }^{234} \mathrm{U} /{ }^{238} \mathrm{U}(\mathrm{B}$ and $\mathrm{D})$ activity ratios and of ${ }^{230} \mathrm{Th}$-ages (E) are plotted for Patella sp. samples (white) and other mollusc shell samples (black). Patella sp. shows a lesser scatter of values (see also Fig. 18). The isotopic signature of its $U$ shows a mode ca 1.14 (Holocene samples; B) and 1.10-1.11 (Last Interglacial samples; D) compatible with a marine origin for most of it.
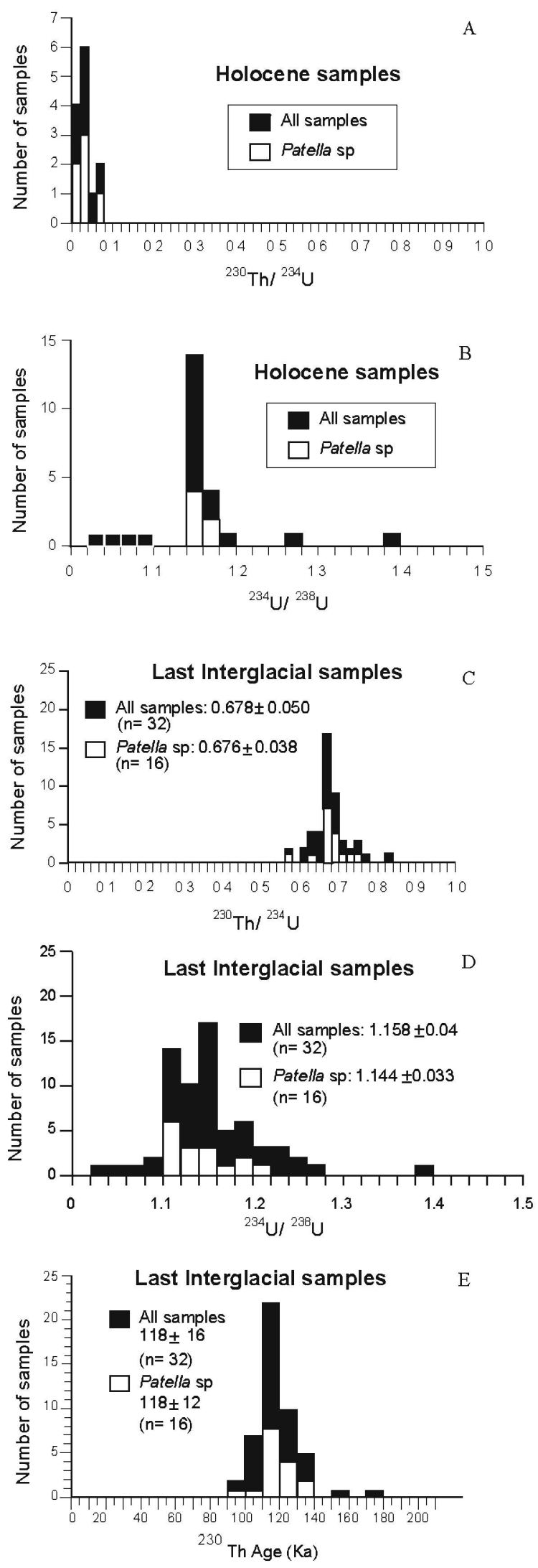

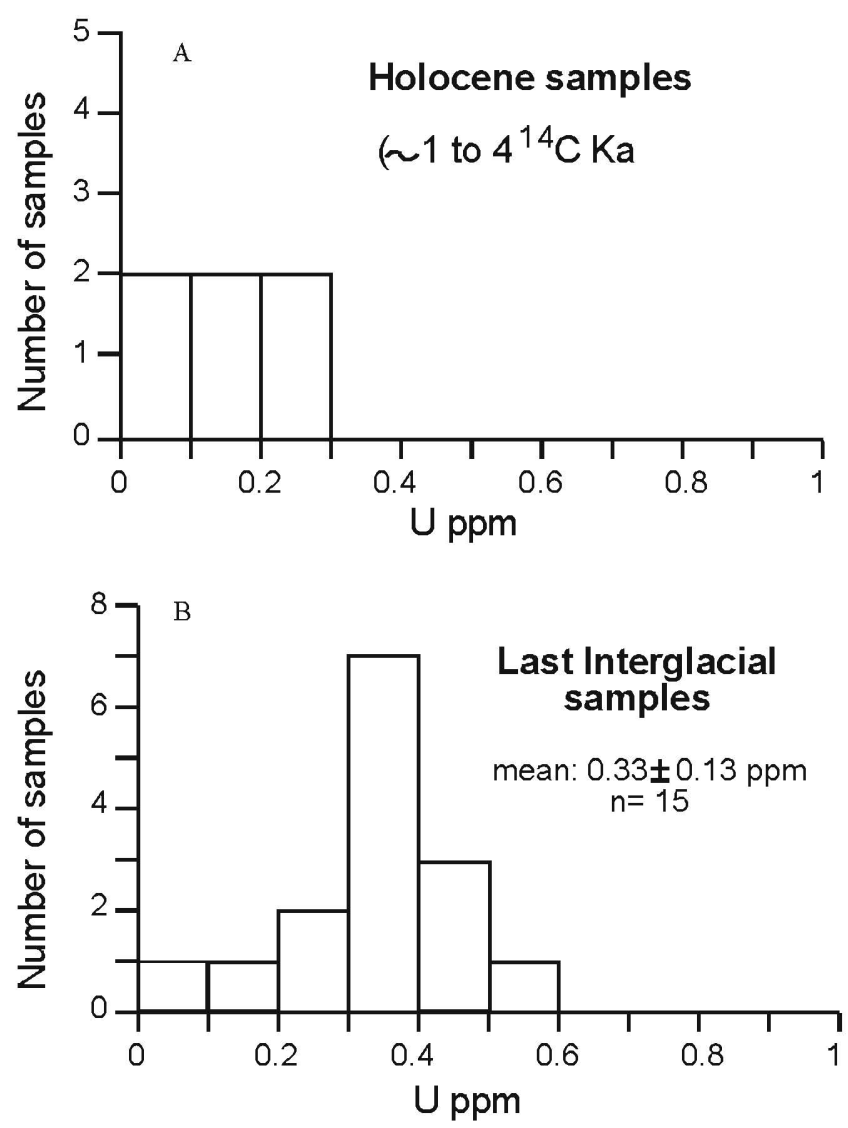

Fig. 9. U-concentrations in Last Interglacial (A) vs. Holocene (B) samples of Patella sp.

still essentially of marine origin. Since most Holocene beach rocks are found within modern tidal range, one may assume that the pore water allowing U-uptake and cementation of the beach-rocks, was seawater. ${ }^{230} \mathrm{Th} /{ }^{234} \mathrm{U}$ ratios in these Holocene samples (Fig. 8A) allow calculation of ${ }^{230} \mathrm{Th}$-ages (Table 2) that do not differ drastically from the ${ }^{14} \mathrm{C}$ ages yielded by the same shells.

The samples collected in the $04 \mathrm{~m}$, of well-cemented marine units that were assigned to the Last Interglacial interval on geomorphological and sedimentological criteria, yielded coherent U-series values, supporting this stratigraphic assignment. However, their U-content show a relatively large range, from $0.1 \sim 1 \mathrm{ppm}$ (Table 2 ), indicating that despite the cementation of the embedding deposits, some late diagenetic uranium was likely incorporated into the shells. Part of this late diagenetic uranium had a higher ${ }^{234} \mathrm{U}$-excess, vs. ${ }^{238} \mathrm{U}$, than the authigenic and early diagenetic fractions (Fig. 8D). Some input from groundwaters thus seems likely here. Nevertheless, all samples from these marine units yielded a relatively narrow histogram of ${ }^{230} \mathrm{Th}$-ages (Fig. 8D), suggesting that most of their U was uptaken during a relatively short and early diagenetic phase.
It is worth noting that the Last-Interglacial Patella sp. shells depict a much narrower distribution of $\mathrm{U}$ concentrations than other taxa, with a conspicuous mode near $0.3 \mathrm{ppm}$ of $\mathrm{U}$ (Fig. 9B). This suggests that they probably constitute a lesser open system, with respect to $U$ mobility, than all other taxa. They also depict a narrower scatter of ${ }^{234} \mathrm{U} /{ }^{238} \mathrm{U}$ ratios, with a mode near 1.1 (Fig. 8D), not much different from that expected for uranium primarily of marine origin, allowing for radioactive decay of its ${ }^{234} \mathrm{U}$-excess since its uptake by the shell. Accordingly, the Patella sp. shells show a slightly narrower scatter of ${ }^{230} \mathrm{Th}$-ages than other taxa (Fig. 8E).

U-series measurements in older units than those of the Last Interglacial have been restricted to a few sites only, because U-series ages in mollusc shells from such units are often inconclusive (e.g., Zazo et al., 1999). The sites that we retained were either sections where Last Interglacial marine units overlay unconformably older marine deposits (Episode X, Punta Pechiguera, Fig. 5), and/or where low-elevation marine units were stratigraphically linked with volcanic sequences (Episode X?, El Cotillo, Fig. 3). As illustrated in Table 2, most yielded finite ${ }^{230} \mathrm{Th}$-ages, notably on Patella sp. samples, but in a range ( $\sim 200 \sim 400 \mathrm{ka}$ ) that does authorize unequivocal stratigraphic interpretation. However, these ages are compatible with an assignment of the corresponding units to any high sea-stand of the isotopic stages 7,9 and possibly 11 , with eventually a higher probability for the isotopic stage 9 , in view of the cluster of ages slightly above $300 \mathrm{ka}$. One feature worth mentioning here is the fact that Patella sp. samples from these older marine units still show a narrow cluster of $\mathrm{U}$ concentrations, near $0.3 \mathrm{ppm}$, with one single exception (LZ92-54; Table 2).

\subsection{AlI data in the studied mollusc shell assemblages}

A summary of allo/isoleucine and total amino acid measurements can be found in Table 3. As explained before, these measurements were done with modest objectives. In the case of Patella sp. samples, they were to be used to ensure proper assignment of samples from unclear outcrops to either Holocene beachrocks or Last Interglacial deposits, or to check that shells to be used for U-series measurements were not reworked from older units. In the other cases (Thais sp. and Ostrea sp.), they were made in order to assess the suitability of such measurements for the setting of an A/I stratigraphy in marine units older than those of the Last Interglacial and Holocene high sea-stands.

As illustrated in Fig. 10 (A and B), Patella sp. shells from Holocene or Last Interglacial (LI) deposits yielded reasonably clustered $\mathrm{A} / \mathrm{I}$ ratios $(0.09 \pm 0.05$ and $0.68 \pm 0.13$, respectively) allowing unequivocal stratigraphic assignment to one or the other of these units. 

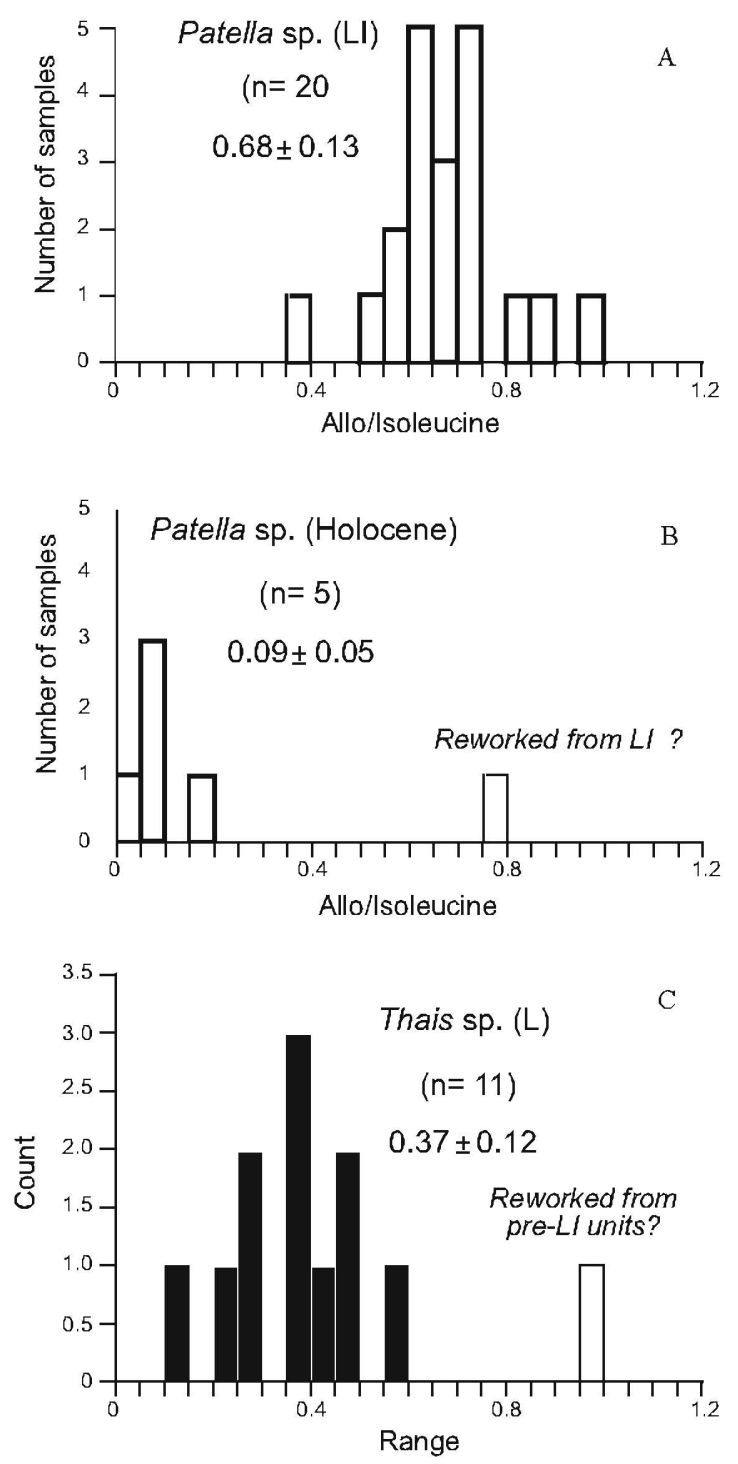

Fig. 10. Allo-isoleucine ratios in Patella sp. and Thais sp. samples. A-Patella sp. from Last Interglacial units; B-Patella sp. from Holocene beach-rocks; C-Thais sp. from Last Interglacial deposits. Both species show a fairly large scatter of values notably due to variable thermal histories, with a lesser scatter for Patella sp. However, $A / I$ ratios in both species, generally allow unequivocal assignment of the marine unit to Holocene, Last Interglacial or undefined older high sea-level episodes.

Patella from pre-LI deposits show more variable ratios, generally exceeding 1 , but too scattered to consider using them for stratigraphic purpose.

$A / I$ ratios in Thais sp. shells of Last Interglacial age depict a scatter of values too large to consider further. Such measurements in these shells can be a useful stratigraphic tool under well-constrained condition. In a similar fashion, A/I ratios in Ostrea sp., even when split at species level (e.g., $O$. virleti, Table 3), sure inconclusive results.
Geomorphological and paleontological criteria together with $\mathrm{U}$-series measurements and $A / I$ values support a Last Interglacial age for Episode XI.

\subsection{Critical sections}

It is necessary to describe briefly some sections that offer particular interest for establishing the chronology of marine Episodes and the related volcanic rocks, and for gathering data concerning sea-level changes suspected of being recorded inside some Episodes. Field data, paleontological results, $\mathrm{U}$-series, $\mathrm{K} / \mathrm{Ar}, A / I$ ratios and paleomagnetic analyses are presented schematically.

\subsection{Lanzarote island}

\subsubsection{Salinas de Janubio-Caletón del Río}

Along the cliffs bordering the Janubio saltpans (Fig. 4), Hernández-Pacheco (1969) cited a Quaternary marine terrace that overlays volcanic rocks of Miocene age, at elevations between 40 and $42 \mathrm{~m}$. Later, Meco (1977) cited $N$. emiliana in marine deposits that overly volcanic rocks at an elevation of $20 \mathrm{~m}$, and dated this layer as Early Pliocene. Coello et al. (1992) described the sequence of volcanic rocks in the escarpment around the Salinas. In ascending stratigraphic order, they found: (1) volcanic materials derived from the Ajaches edifice (14.1 Myr); (2) marine deposit; (3) volcanic materials derived from the Famara edifice $(6.6 \mathrm{Myr})$ the same that Carracedo and Rodríguez-Badiola (1993) assigned to the "Tías? Formation", see Figs. 2 and 4; and (4) topping the sequence, volcanic materials derived from the Atalaya de Femés (0.92 Myr).

Our observations in the area led to the differentiation of four marine terraces (Figs. 4 and 11). The oldest layer is placed at $+40 \mathrm{~m}$ (Episode IV) with a younger encased terrace at $+30 \mathrm{~m}$ (Episode V). Both terraces overlay wave-cut platforms eroded into lavas of Miocene age, and consist of a basal conglomerate followed upwards by bioclastic calcarenites. These two deposits are covered by lavas of the Femés Formation.

An E W section (Fig. 11) exposes three marine terraces incised in the former sequence, corresponding to Episodes VI $(+20 \mathrm{~m}), \mathrm{XI}(+1.5 \mathrm{~m})$ and XII $(+1 \mathrm{~m})$. Episodes XI and XII rest erosively upon the Femés lavas that have been dated in this site as $0.16 \mathrm{Myr}$ (Table 1A). Values of $A / I$ ratios (Table 3 ) suggest a Last Interglacial age for Episode XI and Holocene for Episode XII.

A short distance to the southeast, the cliff of Caletón del Rio (Fig. 12) exposes a marine terrace, with its inner edge at elevation $+10 \mathrm{~m}$ (Episode IX), separating the lavas of Montaña Roja (below) and Femés (above) Formations. The wave-cut platform has been eroded into the volcanic rocks of Montaña Roja and terrestrial deposits. Marine deposits consist of conglomerates with 


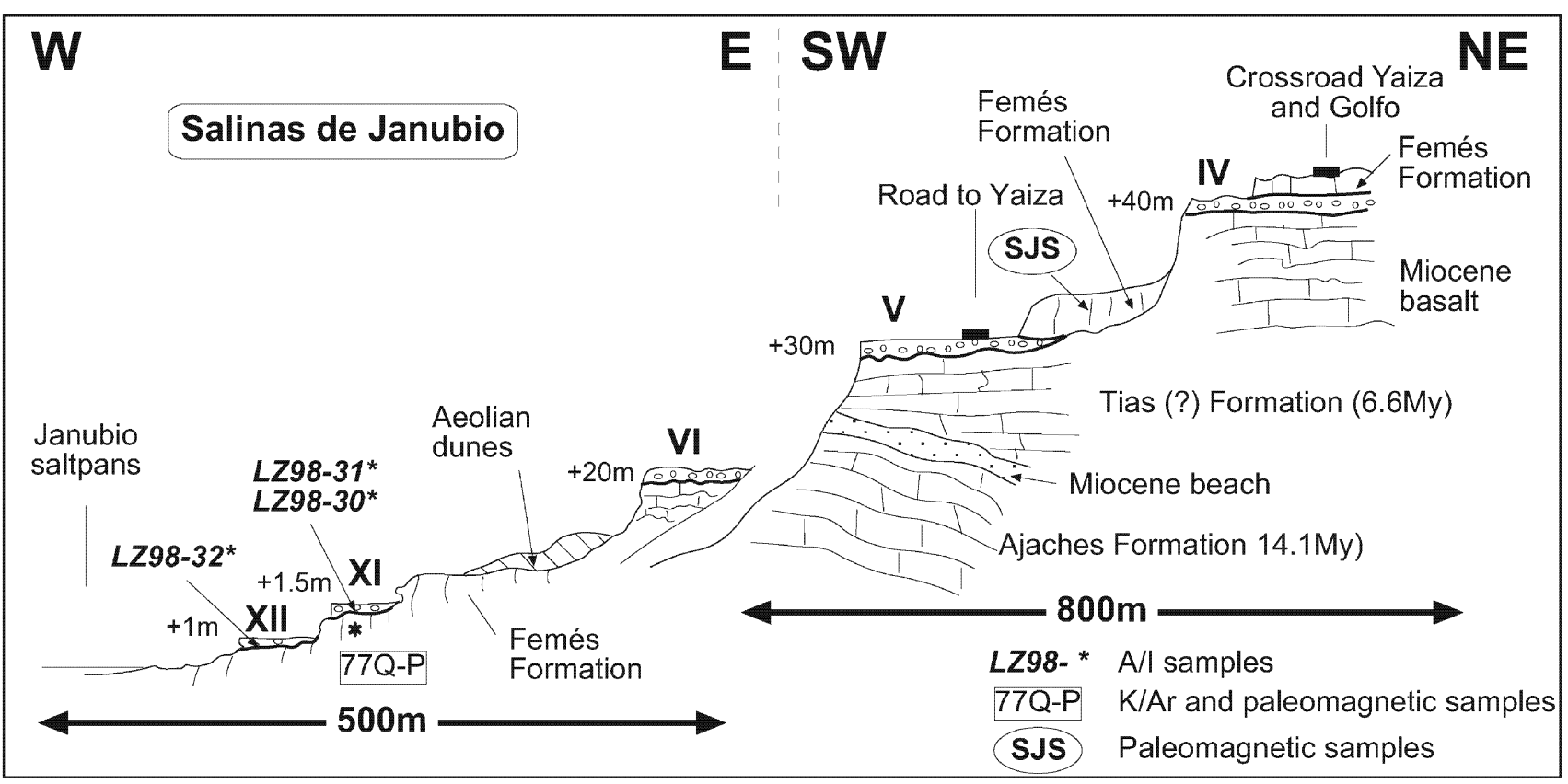

Fig. 11. Sequence of raised marine terraces (Episodes IV, V, VI, XI, and XII) and stratigraphic relations with the lava flows in the cliffs around Salinas de Janubio (SW Lanzarote Island).

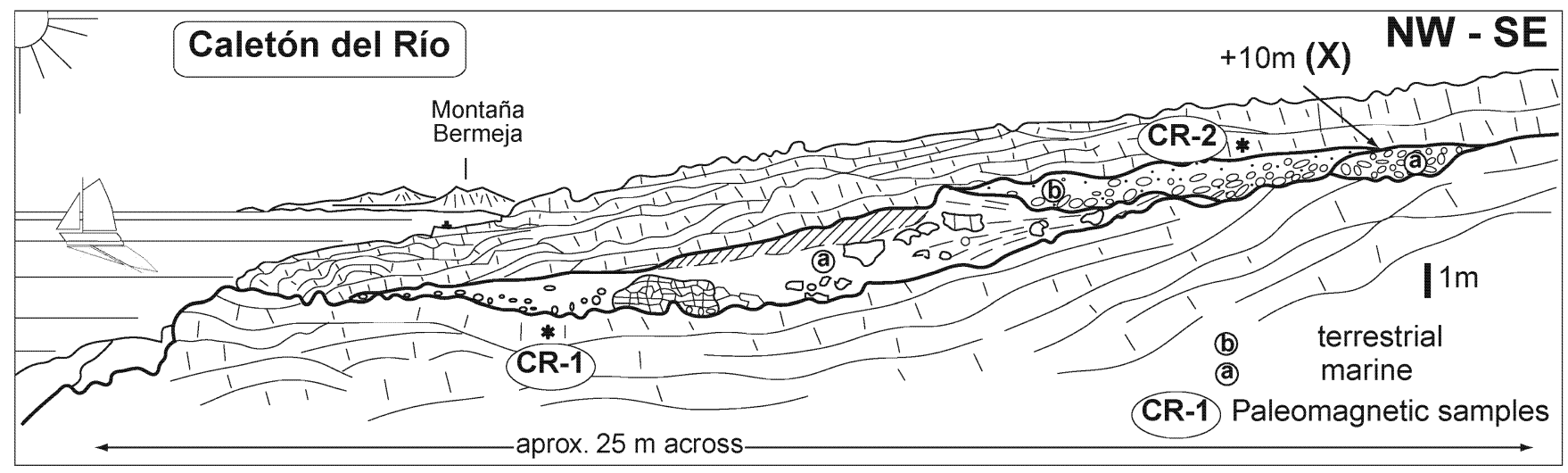

Fig. 12. Diagram drawn from a photograph of the marine terrace (marine Episode IX) interbedded between the Montaña Roja and Femés lava flows in Caletón del Río (SW Lanzarote Island)

bioclasts of marine fossils, that change upwards into bioclastic calcarenites.

Paleomagnetic measurements (samples CR-1 and CR2, Fig. 4, Table 1B) in Caletón del Río indicate a reversed polarity for the lower (Montaña Roja) lavas and normal polarity for the upper (Femés) lavas.

\subsubsection{Punta Pechiguera-La Campana}

Between Punta Pechiguera and la Campana (southwestern extremity of Lanzarote Island, Fig. 4) crops out a sequence of terrestrial and marine deposits that are very interesting because it yields data about sea level changes. The basement is the Montaña Roja basalt
(Fig. 13). K/Ar dating (77 K-P, Table 1A) of a sample collected close to Punta Pechiguera indicates $1.24 \pm 0.02 \mathrm{Myr}$ and paleomagnetic measurements reveal reversed polarity for these lavas.

The most complete sequence can be observed in Punta Pechiguera and includes in ascending stratigraphic order: (1) Massive mixed marine/terrestrial deposit formed by reddish lime mudstone with basalt pebbles and fragments of calcareous crusts. The most abundant fauna is Patella sp. (2) An erosional surface followed by a basal conglomerate that passes upwards into sandstones with large-scale, gently seaward-inclined parallel lamination of the type commonly found in the foreshore 


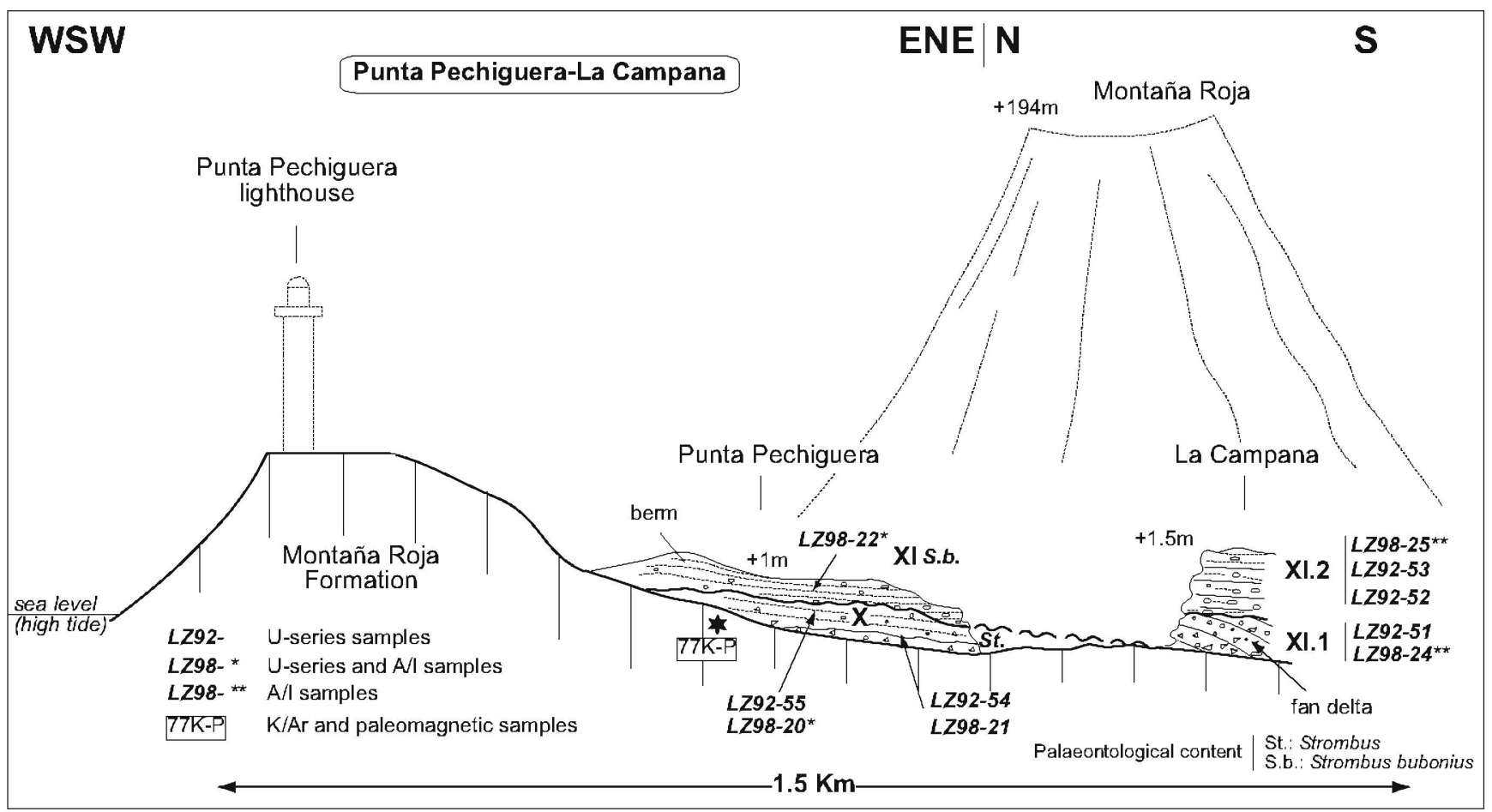

Fig. 13. Correlation of marine Episodes (X and XI) that outcrop between Punta Pechiguera and La Campana, close to the base of Montaña Roja volcano (S Lanzarote Island).

of beaches. This layer yielded shells of "Strombus". These two layers indicate a progressive rise of sea level (Episode X) with age greater than $300 \mathrm{ka}$, according to U-series measurements (Table 2). (3) After a new prominent erosional surface, the next marine deposit forms the top of the sequence. It consists of marine conglomerates, including $S$. bubonius (Episode XI), that onlap the underlying marine deposits, suggesting a new rise of sea level. The age of Episode XI is Last Interglacial (Tables 2 and 3).

Close to this site (Fig. 4) crops out the sequence of La Campana (Fig. 13). Here, the volcanic rocks are covered by prograding fan-deltaic deposits associated to the mouth of a canyon. Then, an erosional surface followed upwards by prograding beach conglomerates with largescale, gently seaward-inclined parallel lamination of the foreshore type. U-series measurements and $\mathrm{A} / \mathrm{I}$ ratios (Tables 2 and 3) give a Last Interglacial age. The twofold arrangement of deposits suggests a fall of sea level (river incision and fan-delta deposition) followed by a rise of sea level (erosion due to the landward-shifting of the surf zone) that culminates during the highstand favouring progradation of the gravel beach face. For this reason they have been named Episode XI.1 (below the erosional surface) and Episode XI.2 (above it).

\subsubsection{El Berrugo}

The sequence of $\mathrm{El}$ Berrugo rests upon the volcanic rocks of Ajaches Formation (Fig. 4). It consists of several layers. In ascending stratigraphic order (Fig. 14): (1) Massive marine/terrestrial layer formed by red clay with angular and rounded pebbles of volcanic rocks, and mixed marine (mostly Patella) and terrestrial (Helix) faunas. (2) Erosional surface. (3) Yellowish calcarenites with marine bivalve shells and $S$. bubonius, and some layers of conglomerate, deposited in the shoreface. (4) Angular unconformity caused by tilting to landwards and partial erosion of the underlying layers. (5) Gravelly unit with embedded boulders of the underlying calcarenites. The faunal content includes $S$. bubonius. To the top of this unit, coarse grain sizes accumulate forming a low ridge interpreted as berm deposits. The overall internal structure is parallel lamination gently inclined to seawards, that passes in that direction to planar cross bedding similar to the plunge step of the lower foreshore. It is interpreted as a prograding gravelly beach face (foreshore) with preserved berm and plunge step. (6) Fossiliferous conglomeratic beach rock encased in the former sequence (Episode XII, Holocene).

$\mathrm{Th} / \mathrm{U}$ data (Table 2) indicate a Last Interglacial age for the whole sequence, corresponding to Episode XI, but has been subdivided (Fig. 14) because of the fall of sea level recorded in the erosional surface separating the calcarenites from the conglomerates. However, a seismo-tectonic origin related to volcanism cannot be ruled out for this sea-level fall (see \#5.1) 


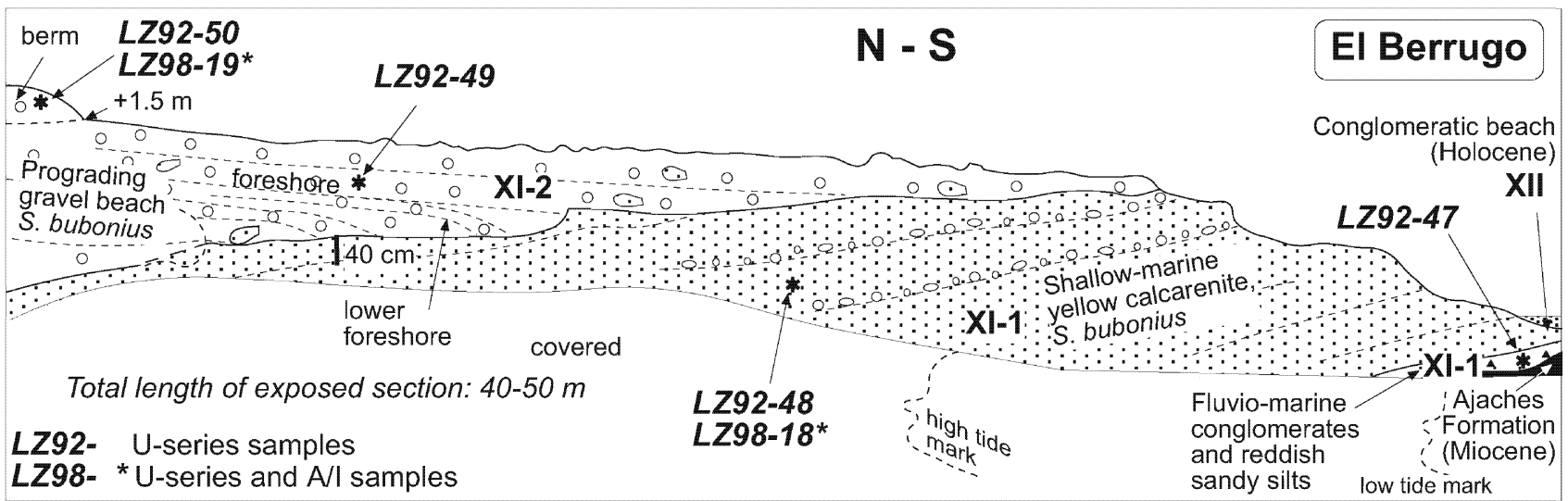

Fig. 14. Marine terraces of Episodes XI (Last Interglacial) and XII (Holocene) and eustatic oscillation (XI.1 and XI.2) inside a single Episode. Tilting to the west of the older deposits (XI.1). El Berrugo (S Lanzarote Island).

\subsubsection{La Respingona}

Lavas derived from Montaña Cavera reached the coast during the sedimentation of a Last Interglacial prograding beach-deposit rich in Patella, breaking and contorting it. Large pieces of deformed beach deposits with recognizable parallel lamination (foreshore facies) occur in contact with the lavas or resting on them (Fig. 15). The same deposits are exposed in the lower part of the sequence found $2.5 \mathrm{~km}$ to the south-east, in La Caleta (Zazo et al., 1997).

U-series measurements in La Respingona and $\mathrm{La}$ Caleta (Table 2) and field data suggest volcanic activity during the Last Interglacial.

\subsubsection{Jameos del Agua, Punta Escamas and Punta Mujeres}

In these sites (Fig. 2), well-cemented marine deposits occur related to lavas derived from the Coronas volcano. In Jameos del Agua and Punta Escamas, beach deposits rest on lavas. On the contrary, lavas drape the beach deposits in Punta Mujeres. Radiocarbon measurements (Table 2) indicate a $\sim 6000 \mathrm{cal} \mathrm{BP}$ age for the last volcanic activity of the Coronas volcano.

\subsection{Fuerteventura Island}

\subsubsection{El Cotillo}

El Cotillo (north-western Fuerteventura Island, Fig. 3) sequence rests on Miocene volcanic rocks (Fig. 16A). Above the erosional surface, a basal conglomerate passes upwards into well-cemented sandstones with conglomeratic layers. Faunal content includes abundant Thais and Patella, the latter indicative of littoral deposition. The sedimentary unit is covered by lavas of the Recent Series (Brunhes) with a notch excavated into them and a little associated bench with some pot holes partly filled with a well-cemented marine conglomerate.

We could make additional observations in a domestic, large diameter, well-hole dug some $100 \mathrm{~m}$ north of the former site. In El Cotillo well (Fig. 16B), the volcanic materials of the Recent Series are eroded by the present platform that cuts open cracks filled with well-cemented marine sediments that, to landwards, form a layer that fossilizes the platform and reaches $0.70 \mathrm{~m}$ in thickness. This marine deposit changes upwards into terrestrial red pebbly mudstones and a reddish-brown paleosoil with preserved Bt (argilic) horizon.

U-series measurements (Table 2) suggest a Last Interglacial age (Episode XI) for the marine deposits that overlay (fill the notches cut into) the volcanic Recent Series. In contrast, results obtained for the marine Episode intercalated between the two volcanic lavas are most doubtful (Episode X?).

The El Cotillo sequence of marine Episodes ends with a conglomeratic beach rock of Holocene age (Episode XII).

\subsubsection{Caleta del Bajo de Mejillones}

A sequence of sedimentary deposits (Fig. 17) is exposed at low tide, overlaying the volcanic rocks of the Recent Series (Brunhes) in the northern coast of Fuerteventura (Fig. 3). Low tide exposes a well-preserved marine terrace, at $+2 \mathrm{~m}$, with a conglomerate of sub-rounded volcanic boulders in a white bioclastic calcarenite matrix. Thais sp. and Patella sp. are abundant. Encased in this terrace and in the volcanic rocks, there is an erosional surface covered by terrestrial reddish mudstone with volcanic lithoclasts. These in turn are eroded and covered by a beach rock of boulders. These, again, are eroded and covered by a littoral ridge with cemented boulders. 

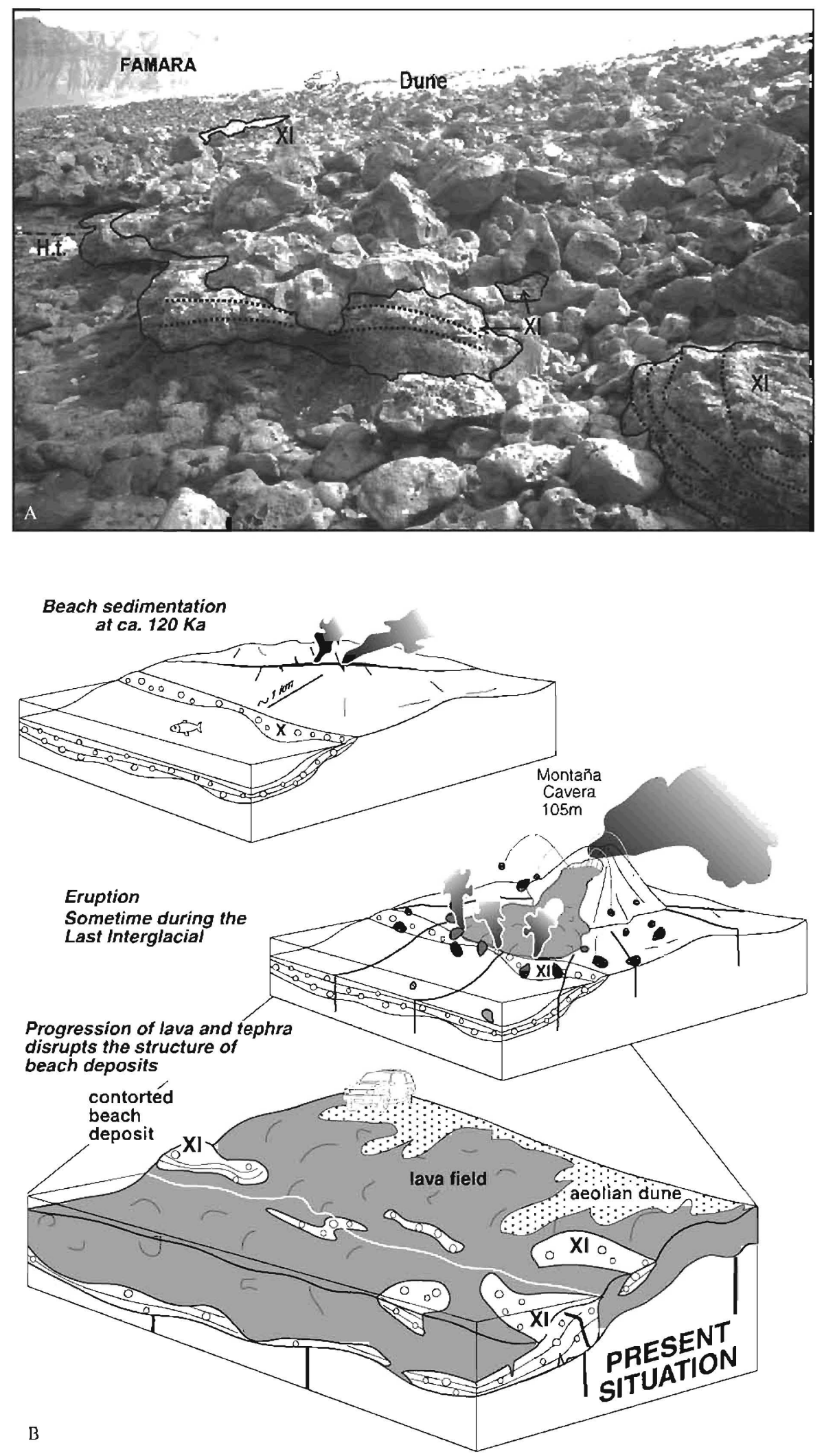

Fig. 15. (A) Fractured and dislodged marine terrace (Episode XI), with deformed foreshore lamination (dotted line) due to pene-contemporaneous push of the lava flows from Montaña Cavera volcano. (B) A reconstruction of the mechanisms involved ca. $120 \mathrm{Ka}$ ago (La Respingona, N Lanzarote Island). 
Several U-series measurements (Table 2) of samples collected from the $+2 \mathrm{~m}$ terrace yield a Last Interglacial age (Episode XI).

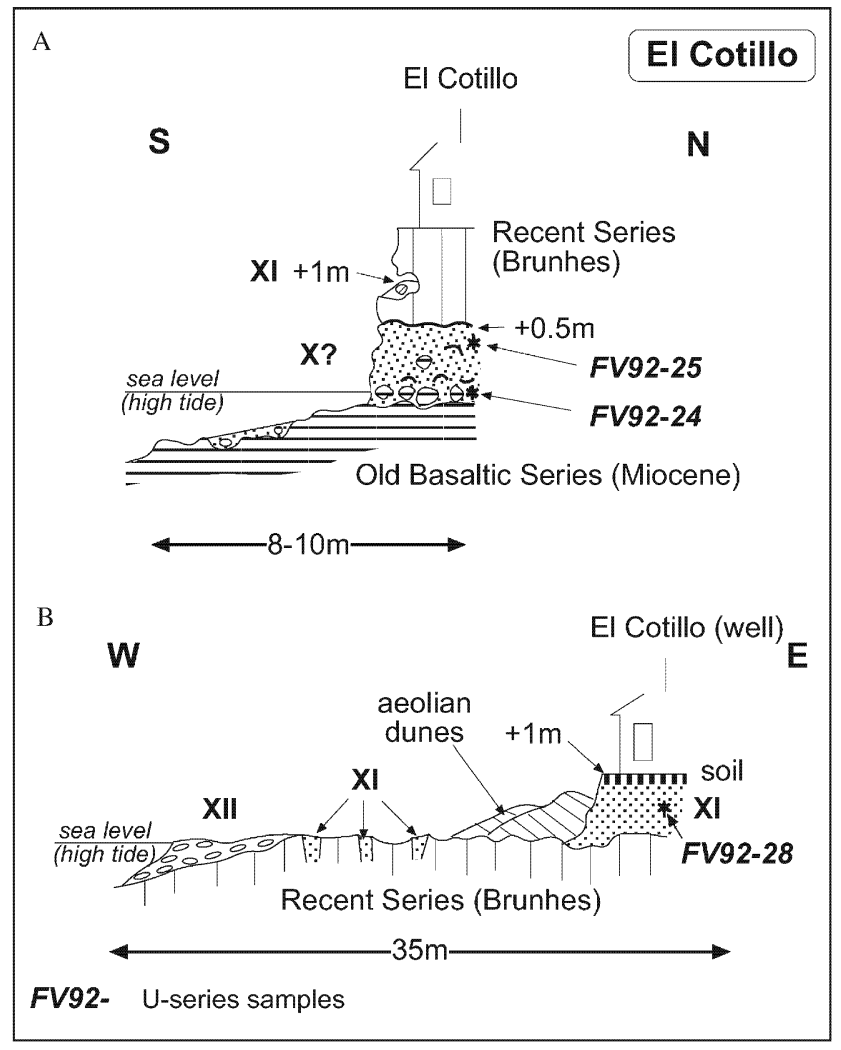

Fig. 16. Marine terraces at El Cotillo (NW Fuerteventura Island). (A) Marine Episode X? interbedded between two volcanic flows. A notch in the younger volcanic unit is filled with a well-cemented marine conglomerate (Episode XI). (B) $100 \mathrm{~m}$ to the north, Episode XI is better developed and was dated as Last Interglacial by means of $\mathrm{U}$ series measurements. A Holocene beach rock (Episode XII) occurs encased in the Episode XI deposits.
U-series and radiocarbon measurements have been carried out in samples of the beach rock and the littoral ridge and yielded a neat Holocene age. However, the morphological arrangement, particularly the spatial position of the littoral ridges (indicated as Holocene and Present in Fig. 17) and the position of the underlying beach rock, strongly suggest oscillations of sea level at least since $\sim 4500$ cal BP. These oscillations (XII.1 and XII.2) do not represent two different highstands. Instead, they are probably related to periods of increased trade winds (Zazo et al., 1997).

\subsubsection{Rosa J. Sánchez}

Low tide exposes a sequence of alternating terrestrial and marine deposits some distance to the north of Puerto del Rosario (Figs. 3 and 18). Terrestrial deposits are alluvial red sandy silts with scattered poorly rounded pebbles. All marine levels correspond to very shallow waters and bear a rich fauna of Patella sp. and Thais haemastoma.

The lowermost marine level is clearly different because it is calcarenitic and finer grained. It underwent early cementation and it is crossed by joints $\left(\mathrm{N} 10-15^{\circ} \mathrm{E}\right)$ filled with conglomerates derived from erosion of younger marine deposits. The top of the lower layer is a prominent erosional surface followed upwards by alluvial-fan deposits including channel-fill facies. The described marine and the intercalated terrestrial deposits suggest that they correspond probably to two highstands.

The results of U-series measurements (Table 2) carried out in deposits of the marine episodes (Table 2) indicate a Last Interglacial age (Episode XI), but sedimentological features of the described marine and intercalated terrestrial deposits strongly suggest the existence of two highstands (XI.1 and XI.2), the younger one including two sea-level oscillations.

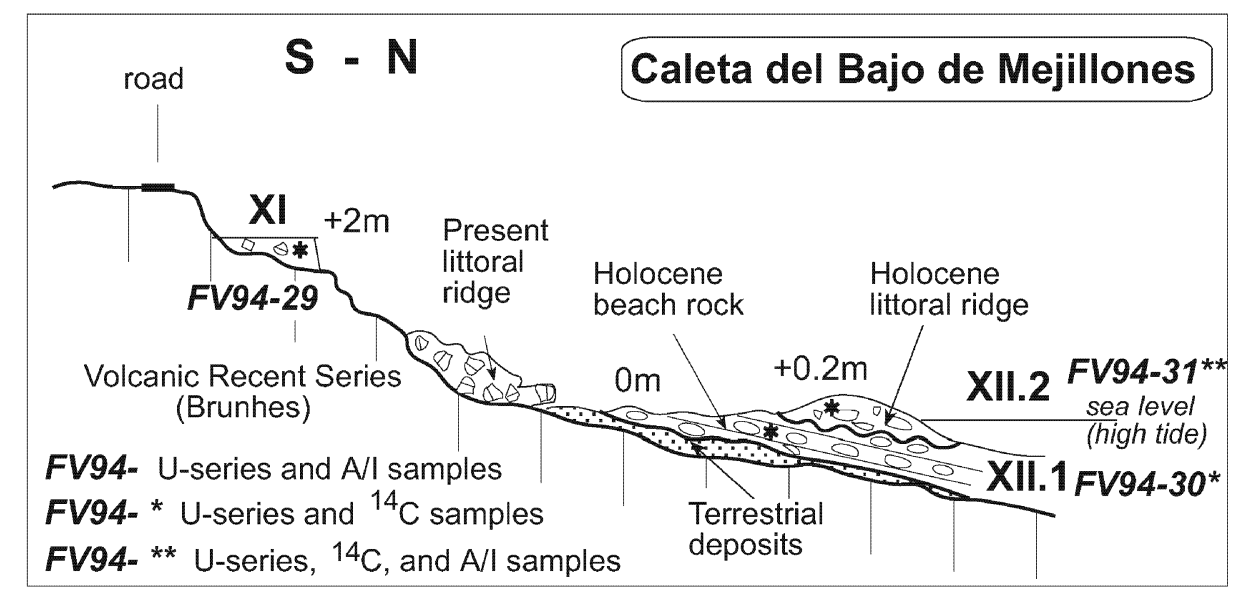

Fig. 17. Marine terraces at Caleta del Bajo de Mejillones (N Fuerteventura Island). Episode XI (Last Interglacial) and two systems of Holocene beach rocks, separated by an erosional surface, that lay upon terrestrial runoff deposits. 


\subsubsection{Aeropuerto (Airport, Puerto del Rosario)}

A shallow creek just off the northern end of the runaway, allows observation of a sequence of two sedimentary units with S. bubonius (Figs. 3 and 19), on top of the Recent Series (Matuyama). Both units are crossed by a system of joints, directed $\mathrm{N} 10-15^{\circ} \mathrm{E}$. In ascending stratigraphic order: (1) Fine-grained, cemented, marine conglomerate with gently inclined parallel lamination that changes downslope into planar cross bedding with paleocurrent direction to seawards. At

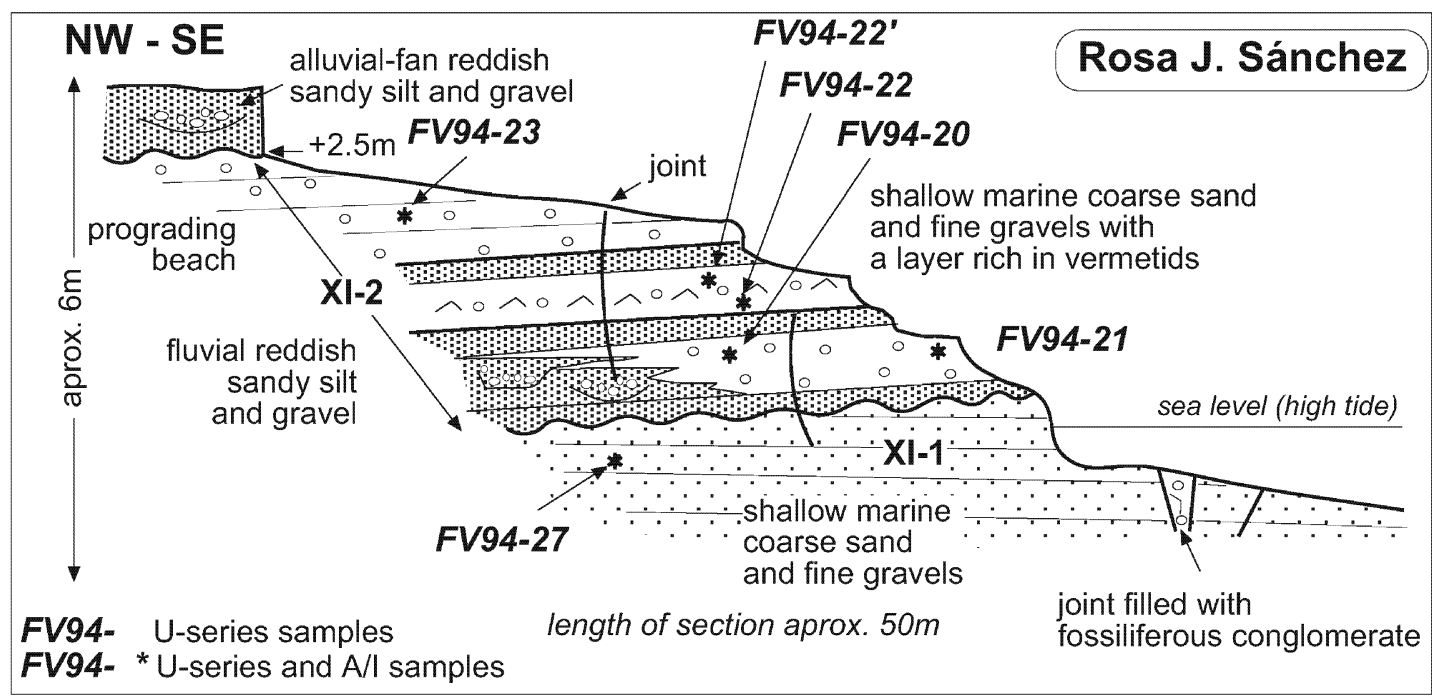

Fig. 18. Alternating marine and terrestrial deposits at Rosa J. Sánchez (E Fuerteventura Island), corresponding to marine Episode XI (Last Interglacial). Two highstands (XI.1 and XI.2) are suggested inside Episode XI. The whole section is affected by a system of joints directed N10-15 ${ }^{\circ} \mathrm{E}$.

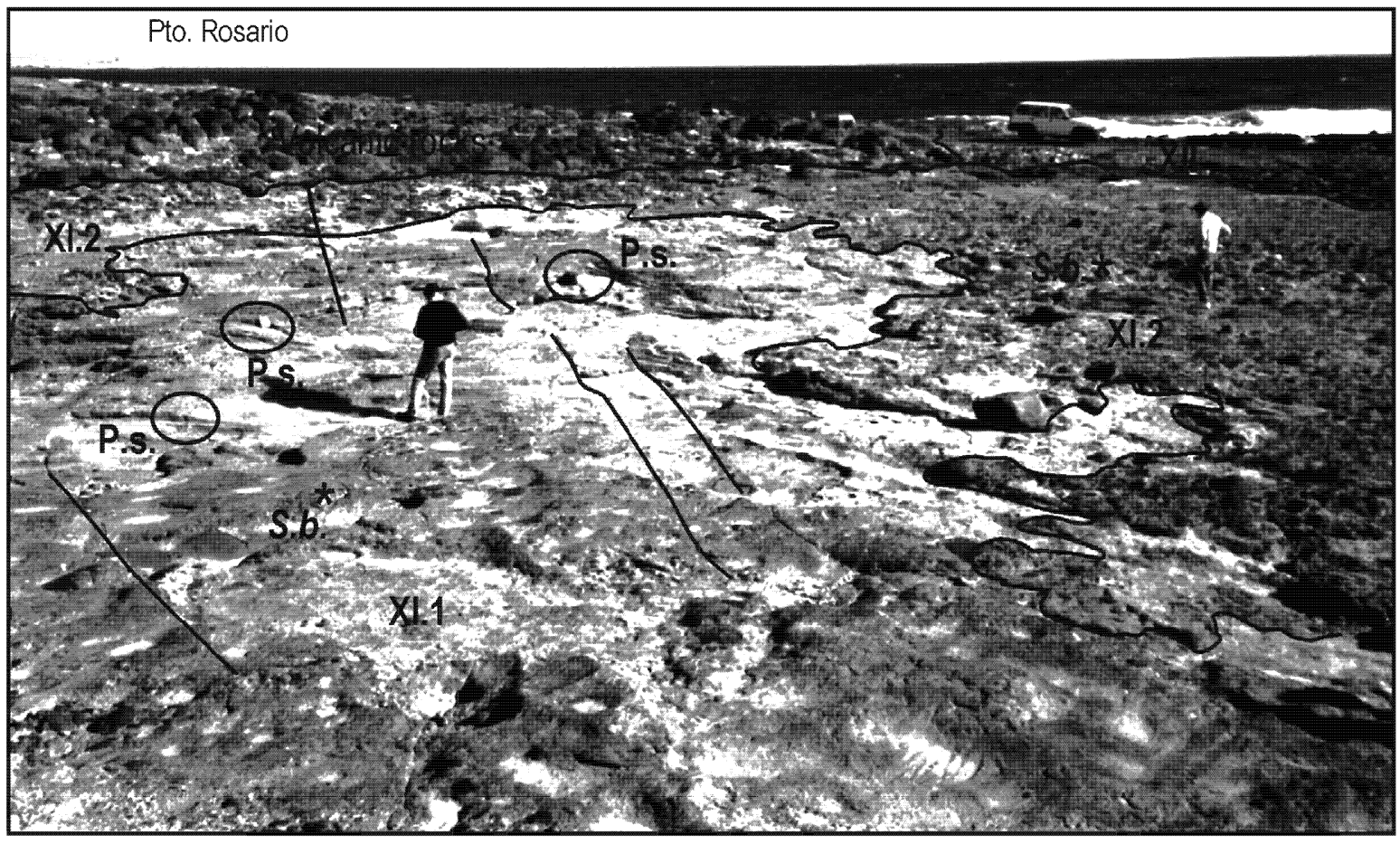

Fig. 19. Deposits of marine Episode XI (Last Interglacial) resting upon the volcanic Recent Series (Matuyama), with basal micro-conglomerates (XI.1) with S. bubonius (Sb). Three plunge-steps (P.s.) indicate temporary positions of the lower foreshore and sea-levels. A younger conglomerate with $S$. bubonius (XI.2) occurs overlapping an erosional surface cut in the XI.1 deposits. Two highstands (XI.1 and XI.2) can be distinguished. A system of fractures (joints) directed $\mathrm{N} 10-15^{\circ} \mathrm{E}$ crosses those deposits (Puerto del Rosario airport, E Fuerteventura Island). Holocene deposits (Episode XII) top the sequence in this locality. The photograph was taken with the camera pointing to $\mathrm{N} 30^{\circ} \mathrm{E}$. 
least three of these sets are observable. They are interpreted as foreshore facies with preserved plungestep (P.s.) in the lower part. This is a typical feature in microtidal coasts, but it is more rarely preserved in mesotidal coasts. The overall structure indicates beach progradation (marine regression) with more or less stable sea level. (2) Erosional surface. (3) Coarse-grained (coarse pebble to boulder size) conglomerate that onlaps the underlying units. The maximum topographic elevation reached by these deposits is $+2 \mathrm{~m}$.

$\mathrm{U}$-series measurements (Table 2) carried out in deposits of the marine episodes indicate a Last Interglacial age (Episode XI). As there is a clear indication of fall of sea level between the two marine units, they are separated as XI.1 and XI.2 (Fig. 19).

Moving in a southward direction, these deposits are observed from Caleta de la Guirra to Punta Hondura (Fig. 3) but here, Episodes XI.1 and XI.2 occur encased. It is noteworthy that in this area the Last Interglacial deposits reach the maximum elevation $(+4 \mathrm{~m})$ measured in the Lanzarote and Fuerteventura Islands.

\section{Discussion}

\subsection{The lava flows and their relationships with the marine episodes}

Our K/Ar data of the Montaña Roja Formation seem to indicate that at least six marine terraces are of Quaternary age (Episodes VII XII), and were deposited after 1.2 Myr. This age value is consistent with our paleomagnetic data and also those from previous authors (Carracedo and Rodríguez-Badiola, 1993). However, it does not fit with other two K/Ar measurements in the same formation (Fig. 4) that yielded values of $0.82 \pm 0.16 \mathrm{Myr}$ (near Rincón del Palo, Meco and Stearns, 1981) and 2.7 $\pm 0.6 \mathrm{Myr}$ (east of Bajo de San Jacinto, Coello et al., 1992).

In Caletón del Río, the terrace at $+10 \mathrm{~m}$ (marine Episode X) overlays the Montaña Roja volcanics, and is covered by the Femés lava flow (Fig. 12). Paleomagnetic data (CR-1 and CR-2, Table 1B) indicate a Pleistocene chronology for this episode.

A K/Ar sample (77Q, Table 1A) taken in the Femés lavas immediately below the $+1.5 \mathrm{~m}$ marine terrace in Salinas de Janubio (Fig. 11) yielded an age of $0.16 \mathrm{Myr}$, compatible with the paleomagnetic data $(77 \mathrm{Q}$ P, Table 1B) and the assigned Last Interglacial age (Episode XI).

Prominent deformation of the marine terrace (Episode XI) in La Respingona suggests volcanic activity associated to Montaña Cavera volcano (Lanzarote Island, Fig. 15) during the Last Interglacial. Tilting of Last Interglacial beach units in El Berrugo (Fig. 14) also suggests tectonic instability of the island. The results of
${ }^{14} \mathrm{C}$ dating (Table 2) of samples collected from the Holocene marine terrace (Episode XII) at Punta Escamas, Punta Mujeres and Jameos del Agua (Fig. 2) suggest a $\sim 6000$ cal BP age for the last activity of the Corona volcano.

\subsection{Occurrence of warm fauna}

All terraces, except the most recent one (Episode XII), contain marine warm faunas. $N$. emiliana, $O$. virleti and Strombus are frequent in Episodes I $(\sim 65 \mathrm{~m})$ to XI $(\sim 8 \mathrm{~m})$ in the two studied islands, with a clear change in the faunal content, recorded in the terrace immediately below, that only contains Strombus. In some places, $S$. bubonius abounds in the marine terrace corresponding to the Last Interglacial (Episode XI), but is typically absent in the northern coasts of both islands.

Strombus species were revealed to be inconclusive for the setting of a precise biostratigraphy because of morphological continuity between $S$. bubonius and $S$. coronatus morphotypes. Many authors have referred to the morphological variability of Miocene, Pliocene and Pleistocene Strombus (Sacco, 1893; Gaibar-Puertas, 1967; Malatesta, 1974; Cuerda, 1989). However, it was precisely the morphological differentiation between both species that led Meco (1977, 1987) and Meco et al. (1997) to consider: (i) all the marine deposits at elevations between $\sim 60$ and $\sim 78 \mathrm{~m}$ in Fuerteventura and Lanzarote islands as a single marine terrace of Miocene-Early Pliocene age with $S$. coronatus, and (ii) all the marine deposits below elevations of $+5 \mathrm{~m}$ (with the exception of the obviously Holocene in age) as a single terrace of Last Interglacial age with $S$. bubonius.

\subsection{Interpretation of $U$-series data on mollusc shells}

The fact that mollusc shells from strongly cemented littoral deposits yield relatively well-clustered U-series ages (Fig. 8) constitutes one of the most interesting outcomes of this study. The early cementation of the beach-rocks constitutes a most favourable condition, since it rapidly ensures a relatively efficient chemical closure for uranium. How fast do beach-rocks form? Field observations indicate variable rates of formation, but at least partial cementation occurs within a few years in many cases. We have found at the El Cotillo site (Fig. 16A and Table 2), a thin, strongly cemented deposit on top of a fossil marine encroachment but within reach of modern high tide waves, that contained a set of empty cases from a machine gun. The age of this beach-rock could not be much greater than a few decades. This does not necessarily mean that this early cementation ensures a total chemical closure, with respect to $\mathrm{U}$-mobility, but rather that it restricts $\mathrm{U}$ mobility. It is also very variable in space. As already mentioned, most Holocene beach-rocks that are often 
strongly hardened in their upper few decimetres, may still be soft and porous below this level.

Nevertheless, the rapid cementation of marine deposits around both islands, almost within modern tidal range, explains the relatively fast and efficient chemical closure of the radioactive system, which is demonstrated by the narrow scatter of ${ }^{230} \mathrm{Th}$-ages from fossil mollusc shells of Last Interglacial age (Fig. 8E). Besides, rapid cementation also allows to understand why the uranium incorporated into the shells often depicts a "marine isotopic signature" (Fig. 8B and D). The pore water leading to beach-rock formation is more likely seawater. Because of the aridity of the eastern Canary Islands, fresh groundwaters are not very abundant, though that is not to say unknown, as in Lanzarote Island. In the vadose zone of the beach, the influence of dissolved uranium from continental waters, that could be more strongly enriched in ${ }^{234} \mathrm{U}$ than seawater, is thus reduced. It does exist, however. This is notably the case at the marine outlet of dry streams, where rain events may result in occasional muddy flows carrying reddish continental clays to the sea, where they mix with beach deposits. In such settings, pore waters with relatively large ${ }^{234} \mathrm{U}$-excesses could be involved in the diagenetic processes. This seems to have occurred, for example, at the Salinas (saltpans) del Berrugo (Table 2; Fig. 14). The Patella sp. shells (LZ92-47) from the lowermost unit, where continental and marine sediments are mixed, indeed show a larger ${ }^{234} \mathrm{U}$-excess than the Patella sp. shells from the truly marine, overlying units (LZ92-48 to 50; Table 2). A similar observation can be made for the nearby site of La Campana, where the mixed marinecontinental lower unit yielded Patella sp. shells slightly enriched in ${ }^{234} U$ (LZ92-51; Table 2), in comparison with the shells from the overlaying truly-marine sediments (LZ92-52 and 53; Table 2).

Interestingly, fossil mollusc shells do not behave in a similar fashion with respect to U-uptake processes. Thus, for a given diagenetic situation, some taxa apparently ensure a relatively efficient closure of the radioactive system, whereas some others do not. Hillaire-Marcel et al. (1996) noticed for example that Arca sp. shells from raised marine deposits of the Balearic Islands fixed uranium during a much longer diagenetic uptake phase than other taxa. This is possibly related to their specific porosity ensuing from the presence in the shell of a network of dense tubules perpendicular to the shell surface (see Waller, 1980). A similar behaviour is depicted here by shells of the gastropod Thais sp., in comparison with those of the pelecypod Patella sp. This is illustrated (Fig. 20) by Useries measurements taken at the site of Mejillones on both taxa (Fig. 14). There, we compared U-series data from live-collected shells, with those of fossils from two superimposed Holocene beach-rocks, and from strongly cemented deposits assigned to the Last Interglacial.

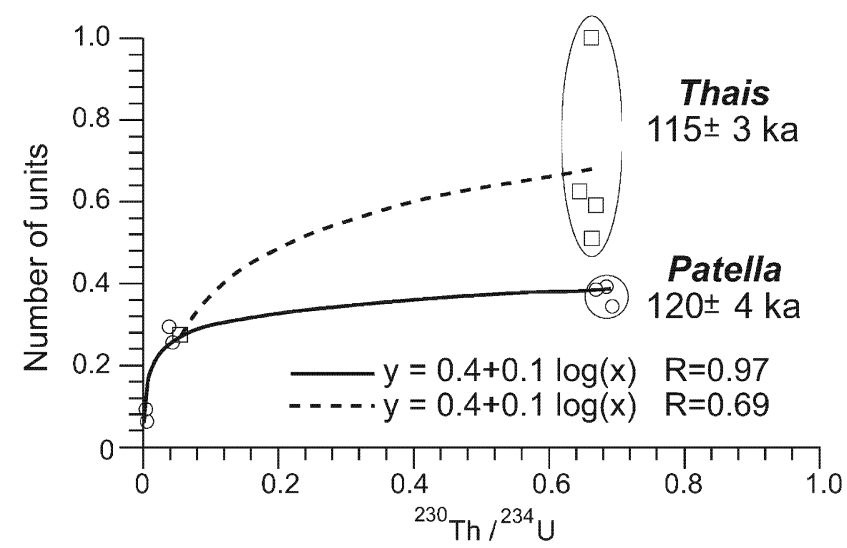

Fig. 20. $\mathrm{U}$ concentrations vs. ${ }^{230} \mathrm{Th} /{ }^{234} \mathrm{U}$ activity ratios in modern, Holocene, and Last Interglacial samples of Patella sp. and Thais sp. at Caleta del Bajo de Mejillones (Fig. 17). Patella sp. of Last Interglacial age show a narrower cluster of values than Thais sp. Their $U$ content is almost equivalent in the Holocene vs. the Last Interglacial samples, suggesting an early diagenetic U-uptake stage, followed by a good chemical closure afterwards. The more open system behaviour of Thais sp. results in a slightly younger mean apparent age of its Last Interglacial samples, compared with that of Patella sp. samples.

Such a comparison seems to indicate that most uranium is uptaken during a shorter diagenetic phase by Patella sp., whereas Thais sp. probably experienced U-uptake during a longer period. The consequence, in terms of ${ }^{230} \mathrm{Th}$-ages, does not appear very significant, but a difference does exist (Fig. 20). In the present example, if we assume that U-uptake process followed approximately the logarithmic equation that seems to fit with the data set of Fig. 20, then ages could be corrected using a U-flux correction model (see also Gruen et al., 1988). The mean age of $\sim 119 \mathrm{ka}$ yielded by the Patella sp. shells would thus correspond to a corrected age of $\sim 121 \mathrm{ka}$. However, U fluxes were unlikely continuous here, given the aridity of the area. The isotopic signature of the uranium incorporated by the Patella sp. shells from the Last Interglacial deposits (Table 2), suggests that most of this uranium was of marine origin. Accordingly, we may presume that it is has been incorporated into the shell when marine pore waters were still present in the deposits, i.e., during the high sea-stand interval itself, before sea-level fall. One cannot discard the possibility of some recent U-uptake by the shells, in relation to the Holocene transgression that allowed sea water to be present again at the elevation of the last-interglacial marine deposits. However, the strong cementation of this unit, and the fact that its calcite cement yielded a ${ }^{230}$ Th-age near $100 \mathrm{ka}$ (Table 2), would rather lead to neglect the incidence of such a secondary U-uptake phase on the calculated ages. In a similar fashion, secondary losses of $U$ that could have resulted from the percolation of water under oxidizing conditions, through the fossils, should be negligible, if any. We may conclude here that the true age of the 
Patella sp. shells, therefore that of the embedding deposits, should not be much different from their mean ${ }^{230}$ Th-age.

\subsection{Raised marine terraces and isotopic stages}

Since the work of Shackleton and Opdyke (1973, 1976) on deep-sea cores V28-238 and V28-239, the chronostratigraphy of the Pleistocene has been closely linked to the Oxygen-Isotope stratigraphy. However, there are still some discrepancies between the $\delta^{18} \mathrm{O}$ curve from SPECMAP and the record obtained from ice and land cores, particularly in relation with the duration of every interglacial, the number of highstands recorded in each interglacial, and the topographic elevation reached by sea level during a highstand. SPECMAP data suggest sea levels similar to the present during MIS 11,9 and 5e.

Studies of ice records (GRIP, 1993) led to new interpretations about the consideration of a stable climate just a few degrees warmer than today during the peak of MIS 5e, as had been widely assumed from the deep sea data. A great climatic instability during this peak ( $\sim 110130 \mathrm{ka})$ is recorded. The climatic instability also produced sea-level changes that have been recorded and detected in raised terraces of many localities around the world. This is the case in the coasts of Pacific (Goy et al., 1992; Ortlieb et al., 1994) and Atlantic oceans (Hearty and Kindler, 1995; Hearty and Kaufman, 2000; Blanchon and Eisenhauer, 2001), Mediterranean sea (Zazo et al., 1993; Hillaire-Marcel et al. 1996; Kindler et al., 1997), Red sea and Gulf of Suez (Plaziat et al., 1998). The exact elevation of sea level during MIS 5e is still somewhat unclear. Recent well-dated records suggest a typical elevation of $+2 \mathrm{~m}$ (Murray-Wallace et al., 1998; Hearty and Kaufman, 2000) during this interval ( $\sim 130117 \mathrm{ka})$. Recent studies (Petit et al., 1999) from Vostok ice core for the last $420 \mathrm{ka}$ suggest that interglacials 5.5 and 9.3 are similar to each other in duration (17 and $20 \mathrm{ka}$, respectively), shape and amplitude. Besides, both events include a warm period lasting $4 \mathrm{ka}$. Stage 7.5 is different and shorter-lived ( $7 \mathrm{ka}$ ). Many papers have dealt with MIS 11 , an interval extending between 420 and $360 \mathrm{ka}$ (Droxler and Farrell, 2000 ) that was the longest and warmest interglacial interval in the past $500 \mathrm{ka}$. However, these authors indicate that it is not easy to determine the degree of warming during MIS 11.

From these considerations it is evident that there are still many discrepancies and uncertainties regarding the records obtained from the deep-sea, ice-cores, and land records.

The most complete sequence of raised marine terraces in the Eastern Canary Islands includes 12 terraces, found at approximately the same elevations along the southern coasts, of both islands, located at elevations between +65 and $0 \mathrm{~m}$.
Morphostratigraphic results together with $\mathrm{K} / \mathrm{Ar}$ and $\mathrm{U}$-series data in Lanzarote and Fuerteventura Islands suggest the existence of seven marine terraces, equivalent to seven Pleistocene Interglacials formed in the last $1.2 \mathrm{Ma}$.

We assimilate the $+0.5 \mathrm{~m}$ terrace (marine Episode XII) to MIS 1, and the $+2 \mathrm{~m}$ terrace (Episode XI) containing $S$. bubonius, should represent MIS 5e that often includes two well-differentiated highstands. The terrace representing Episode $\mathrm{X}$ occurs only in south Lanzarote, where it contains abundant Strombus, and, probably, also in north-western Fuerteventura. As radiometric ages cluster slightly above $300 \mathrm{ka}$, we assume that it records MIS 9.

These three terraces occur clearly encased in Episode IX (terrace at $+810 \mathrm{~m}$ ), that is the youngest one found in the two islands that contains the warm fauna of $N$. emiliana, $O$. virleti and Strombus. Therefore, it seems reasonable to assign it to MIS 11.

The absence of a marine Episode corresponding to MIS 7 may be related to: (i) its position below present sea level or (ii), erosion during the highstand of MIS $5 \mathrm{e}$. We think that the first hypothesis is more likely (see \#5.5).

It is much more problematic to correlate the older terraces with a given MIS. In any case, as Episodes VII XII overlay the lavas of Montaña Roja, they must be younger than 1.2 Myr (Fig. 4). It is logical to think that at least some of Episodes VI I should be of Quaternary age. Besides, considering the morphosedimentary and faunal similarity of all the raised terraces between 0 and $+70 \mathrm{~m}$, the whole set might probably be of Quaternary age. Older marine and transitional (fan delta) deposits have been observed in the walls of the valleys near El Pimentero, in Los Ajaches, below the raised marine terraces associated to the Hacha Chica relief.

\subsection{Paleo sea-levels and vertical movements}

Patterns of vertical deformation can be inferred from the study of emerged marine terraces. However, in neotectonic studies dealing with vertical movements of the coastal zone, two problems must be addressed: the age determination of emerged shorelines, and the original position of the sea level at the time when the terrace was formed. Moreover, in order to quantify the motions, we need to assume, at least initially, a constant movement and a similar trend (uplift or subsidence).

Based on the elevation of the $1718 \mathrm{~m}$ asl terrace (marine Episode VII) and assuming that this terrace was formed practically at the same time $(1.2 \mathrm{Myr})$ as the underlying lava flow, the mean uplift rate is $1.7 \mathrm{~m} / \mathrm{ka}$. However, there are two facts that must be taken into consideration: (i) the present mean elevation of the terrace corresponding to MIS 5e (marine Episode XI) is $1 \mathrm{~m}$ asl in Lanzarote, and $2 \mathrm{~m}$ in Fuerteventura. (ii) it is 
widely agreed that the sea reached an elevation $2 \mathrm{~m}$ asl higher than the present at that time. According to this, we must conclude that the Island of Fuerteventura has remained more or less stable in the last $\sim 130 \mathrm{ka}$, whereas Lanzarote experienced some subsidence with rates in the order of $0.7 \mathrm{~cm} / \mathrm{ka}$ in the same period.

On the other hand, if we correctly assigned Episode $\mathrm{X}$ (terrace at $+1 \mathrm{~m}$ ) to MIS 9 , then we can conclude that the change from uplift to subsidence or "stability" probably took place in the last $\sim 300 \mathrm{ka}$.

\section{Conclusions}

The major findings of the present study, with reference to previous publications, identity the following:

(i) Detailed mapping of the marine and terrestrial deposits have established the stratigraphic architecture and relationship with the volcanic rocks in two areas of Fuerteventura and Lanzarote Islands where the sequence of raised marine terraces is more complete and best exposed. This has allowed correlation with isolated outcrops in the littorals of the two islands. Maps, cross-sections, and morphosedimentary analysis has proved to be critical for selecting the best sampling sites for laboratory techniques: K/Ar dating, paleomagnetic analysis, $\mathrm{U}$-series, allo-isoleucine measurements and radiocarbon dating. Twelve marine terraces (marine Episodes I XII in ascending stratigraphic order, between +70 and $0 \mathrm{~m}$ ) have been distinguished, with similar elevations and facies arrangements on the two islands.

(ii) The $\mathrm{K} / \mathrm{Ar}$ ages (1.2 Myr) obtained for the volcanic Montaña Roja Formation (Lanzarote) forming the basement of the seven younger marine terraces (Episode VII XII) indicate a Quaternary age. There is no geochronological control for the older terraces located between $+2530 \mathrm{~m}$ (Episode VI) and $+6570 \mathrm{~m}$ (Episode $\mathrm{I}$ ), but it is probable that most of them are of Pleistocene age because their morphosedimentary features and faunal contents are similar to those of the more modern Episodes.

(iii) Temperatures of superficial seawaters during the time span of terrace generation were higher than at present (Holocene marine Episode XII), as suggested by the warm faunas found in all the marine terraces. However, a change in the typical assemblage (Strombus, $O$. virleti, and $N$. emiliana) took place after the deposition of the $+810 \mathrm{~m}$ terrace (marine Episode IX) but before deposition of the terrace at $+1 \mathrm{~m}$ (marine Episode $\mathrm{X}$ ). The change is highlighted by the disappearance of $O$. virleti, and
$N$. emiliana, and it is assumed to have occurred probably between MIS 11 and MIS 9.

(iv) The general uplift trend in both islands is about $1.7 \mathrm{~cm} / \mathrm{ka}$ for the last Myr. The present topographic elevation of the MIS 5e terrace evidences a change to more or less stable conditions in Fuerteventura and a slight subsidence in Lanzarote in the order of $0.7 \mathrm{~cm} / \mathrm{ka}$, that probably began about $300 \mathrm{ka}$ ago.

(v) The uncertainties in the past eustatic sea-level estimates, as well as the tectonic behaviour of the eastern Canary Islands, lead us to conclude that unequivocal assignment of raised marine features to given high sea-level stages inferred from the marine isotopic stratigraphy is impossible, unless they are recent highstands that fall within $\mathrm{U}$-series time control.

\section{Acknowledgements}

The authors are deeply indebted to Dr. Manuel Hoyos (deceased, 1999), a pioneer who dedicated years to the study of the Quaternary deposits in Canary Islands and inspired us with his enthusiasm. Thanks also to Mrs. Louise Cournoyer (GEOTOP-UQAM, Canada) for her help with A/I measurements. Javier Lario assisted in the calibration software. Financial support from: Spanish Dirección General de Enseñanza Superior (DGES) Projects PB98-0514, PB98-0265, BTE20001311, Areces Project "Registro geológico y cambios climáticos" (1997 2000), NSERC-Canada and FCAR Funds of Quebec. This is a contribution to IGCP Project 437 (Coastal environmental change during sealevel highstands) and to the INQUA Sea Level Change and Neotectonic Commission.

\section{References}

Ancochea, E., Brandle, J.L., Cubas, C.R., Hernán, F., Huertas, M.J., 1996. Volcanic complexes in the eastern ridge of the Canary Islands: the Miocene activity of the island of Fuerteventura. Journal of Volcanology and Geothermal Research 70, 183-204.

Blanchon, P., Eisenhauer, A., 2001. Multi-stage reef development on Barbados during the Last Interglaciation. Quaternary Science Reviews 20, 1093-1112.

Cande, S.C., Kent, D.V., 1995. Revised calibration of the geomagnetic polarity time scale for Late Cretaceous and Cenozoic. Journal of Geophysical Research 100 (B4), 6093-6095.

Carracedo, J.C., Rodríguez-Badiola, E., 1993. Evolución geológica y magmática de la isla de Lanzarote (Islas Canarias). Revista de la Academia Canaria de la Ciencia 4, 25-58.

Carracedo, J.C., Day, S., Guillou, H., Rodríguez Badiola, E., Canas, J.A., Pérez Torrado, J.F., 1998. Hotspot volcanism close to a passive continental margin: the Canary Islands. Geological Magazine 135 (5), 591-604.

Cassignol, C., Gillot, P.Y., 1982. Range and Effectiveness of Unspiked Potassium-Argon Dating: Experimental Groundwork and Applications. Wiley, New York, pp. 159-179. 
Chen, J.H., Edwards, R.L., Wasserburg, G.J., 1986. ${ }^{238} \mathrm{U},{ }^{234} \mathrm{U}$ and ${ }^{232}$ Th in sea water. Earth Planetary Science Letters 80, 241-251.

Coello, J., Cantagrel, J.M., Hernán, F., Fúster, J.M., Ibarrola, E., Ancochea, E., Casquet, C., Jamond, C., Díaz de Terán, J.R., Cendrero, A., 1992. Evolution of the eastern volcanic ridge of the Canary Islands based on new K-Ar data. Journal of Volcanology and Geothermal Research 53, 251-274.

Crofts, R., 1967. Raised beaches and chronology in north west Fuerteventura, Canary Islands. Quaternaria 9, 247-260.

Cuerda, J. 1989. Los tiempos cuaternarios de las Baleares. Dirección General de Cultura. Conselleria de Cultura, Educació I Esports. Govern Balear, Mallorca, Spain, pp. 1-305.

Driscoll, E.M., Hendry, G.L., Tinkler, K.J., 1965. The geology and geomorphology of Los Ajaches, Lanzarote. Geological Journal (Liverpool) 4, 321-334.

Droxler, A.W., Farrell, J.W., 2000. Marine Isotope Stage 11 (MIS 11): new insights for a warm future. Global Planetary Change 24, 1-5.

Edwards, R.L., Chen, J.H., Wasserburg, G.J., 1987. ${ }^{238} \mathrm{U}-{ }^{234} \mathrm{U}-{ }^{230} \mathrm{Th}-{ }^{232} \mathrm{Th}$ systematics and the precise measurement of time over the past 500,000 years. Earth and Planetary Science Letters $81(2-3), 175-192$.

Fontes, J.C., Gasse, F., Gibert, E., 1996. Holocene environmental changes in Lake Bangong Basin (western Tibet); Part 1, chronology and stable isotopes of carbonates of a Holocene lacustrine core. Palaeogeography, Palaeoclimatology, Palaeoecology 120, 25-47.

Fuster, J.M., Carracedo, J.C., 1979. Magnetic polarity mapping of Quaternary volcanic activity of Fuerteventura and Lanzarote (Canary Islands). Estudios Geológicos 35, 59-65.

Fuster, J.M., Fernández Santin, S., Sagredo, J., 1968a. Geology and volcanology of the Canary Islands, Lanzarote. Instituto Lucas Mallada, Consejo Superior de Investigaciones Científicas, Madrid, $177 \mathrm{pp}$.

Fuster, J.M., Cendrero, A., Gastesi, P., Ibarrola, E., López Ruiz, J., 1968b. Geology and Volcanology of Canary Islands, Fuerteventura. Instituto Lucas Mallada, Consejo Superior de Investigaciones Científicas, Madrid, 239pp.

Gascoyne, M., 1992. The geochemistry of actinides and their daughters. In: Ivanovich, M., Harmon, R.S. (Eds.), Uraniumseries Disequilibrium: Application to Earth, Marine, and Environmental Sciences. Oxford Science Publication, Clarendon press, Oxford, UK, pp. 34-61.

Gaibar-Puertas, G., 1967. Dimorfismo y biometría del Strombus albergado por las terrazas eutirrenienses del sureste peninsular. Boletín Sociedad Española de Historia Natural (Geología) 65, 33-34.

Gillot, P.Y., Cornette, Y., 1986. The Cassignol technique for potassium-argon dating, precision and accuracy: examples from late Pleistocene to recent volcanics from southern Italy. Chemical Geology 59, 205-222.

Goy, J.L., Macharé, J., Orlieb, L., Zazo, C., 1992. Quaternary shorelines and neotectonics in southern Perú: the Chala embayment. Quaternary International 15-16, 99-112.

GRIP ICL-Core Project Members, 1993. Climatic instability during the last interglacial period recorded in the GRIP ice core. Nature, 364, 203-207.

Gruen, R., Schwarcz, H., Chadam, J., 1988. ESR dating of tooth enamel; coupled correction for U-uptake and U-series disequilibrium. Nuclear Tracks and Radiation Measurements 14, 237-241.

Hare, P.E., Abelson, P.H., 1968. Racemization of amino acids in fossil shells. Year Book Carnegie Institution, pp. 526-528.

Hearty, P.J., Kindler, P., 1995. Sea-level high-stand chronology from stable carbonate platforms (Bermuda and the Bahamas). Journal of Coastal Research 11 (3), 675-689.

Hearty, P.J., Kaufman, D.S., 2000. Whole-rock aminostratigraphy and Quaternary sea-level history of the Bahamas. Quatemary Research 54, 163-173.
Hernández-Pacheco, F., 1969. Los niveles de playas cuaternarias de Lanzarote. Revista de la Real Academia de Ciencias Exactas, Físicas y Naturales de Madrid, Tomo 63 (4), 903-961.

Hillaire-Marcel, C., Ghaleb, B., Gariépy, C., Zazo, C., Hoyos, M. Goy, J.L., 1995. U-series dating by the TIMS technique of land snails from paleosols in the Canary Islands. Quaternary Research $44,276-282$.

Hillaire-Marcel, C., Gariépy, C., Ghaleb, B., Goy, J.L., Zazo, C., Cuerda, J., 1996. U-series measurements in Tyrrhenian deposits from Mallorca - further evidence for two last-interglacial high sea levels in the Balearic Islands. Quaternary Science Reviews 44, $276-282$.

Kaufman, A., Ghaleb, B., Wehmiller, J.F., Hillaire-Marcel, C., 1996. Uranium concentration and isotope ratio profiles within Mercenaria shells: geochronological implications. Geochimica and Cosmochimica Acta 60 (19), 3735-3746.

Kindler, P., Davaud, E., Strasser, A., 1997. Tyrrhenian coastal deposits from Sardinia (Italy): a petrographic record of high sea levels and shifting climate belts during the last interglacial (isotopic substage 5e). Palaeogeography, Palaeoclimatology, Palaeoecology $133,1-25$

Labonne, M., Hillaire-Marcel, C., 2000. Geochemical gradients within modern and fossil shells of Concholepas concholepas from Northern Chile: an insight into U-Th. Geochemica and Cosmochimica Acta 64, 1523-1534.

Lecointre, G., Tinkler, K.J., Richards, G., 1967. The marine Quaternary of the Canary Islands. Academy of Natural Science of Philadelphia Proceedings 119, 325-344.

Leonard, E.M., Wehmiller, J.F., 1992. Low uplift rates and terrace reoccupation inferred from mollusk aminostratigraphy, Coquimbo Bay area, Chile. Quaternary Research 38, 246-259.

Malatesta, A., 1974. Malacofauna pliocenica Umbra. Memoria Servicio Carta Geográfica d'Italia, Vol. 13, Roma, 498pp.

Meco, J., 1977. Los Strombus neógenos y cuaternarios del Atlántico euroafricano, taxonomía, biostratigrafía y paleoecología. Ph.d. Thesis, Universidad Complutense de Madrid, 1976, Cabildo Gran Canaria. 207pp.

Meco, J., 1987. Islas Canarias. In: Mapa del Cuaternario de España E:1:1.000.000. Instituto Tecnológico y Geominero, pp. 233-243.

Meco, J., Stearns, C.E., 1981. Emergent littoral deposits in the Eastern Canary Islands. Quaternary Research 15, 199-208.

Meco, J., Petit-Maire, N., Fontugne, M., Shimmield, G., Ramos, A.J., 1997. The Quaternary deposits in Lanzarote and Fuerteventura (Eastern Canary Islands, Spain): An overview. In: Meco, J., PetitMaire, N. (Eds.), Climates of the Past. Proceeding CLIP Project, 1995 , pp. $123-136$

Mitterer, R.M., 1993. Diagenesis of proteins and amino acids in fossil shells. In: Macko, S.A., Engel, M.H. (Eds.), Organic Geochemistry. Plenum Press, New York, pp. 739-751.

Murray-Wallace, C.V., Belperio, A.P., Cann, J.H., 1998. Quaternary neotectonism and intraplate volcanism: the Coorong to Mount Gambier Coastal Plain, southeastem Australia: a review. In: Stewart, I.S., Vita-Finzi, C. (Eds.), Coastal Tectonics. Geological Society.Special Publications, London, Vol. 146, pp. 255-267.

Ortlieb, L., Ghaleb, B., Hillaire-Marcel, C., Machare, J., Pichet, P., 1992. Déséquilibres U/Th, rapports D-alloisoleucine/L-isoleucine et teneurs en ${ }^{18} \mathrm{O}$ des mollusques de dépots littoraux pléistocènes du sud du Pérou; une base d'appreciation chronostratigraphique. Compte Rendue de l'Academie de Sciences Paris, Série 2, 314 (1), 101-107.

Ortlieb, L., Macharé, J., Goy, J.L., Zazo, C., 1994. Secuencias de terrazas marinas cuaternarias en la región de Chala, Perú central Interpretación morfoestratigráfica y neotectónica. VII Congreso Peruano de Geología (Lima). Extended Abstracts vol., 242-245.

Petit, J.R., Jouzel, J., Raynaud, D., Barkov, N.I., Barnola, J.M., Basile, I., Benders, M., Chappellaz, J., Davis, M., Delaygue, G., 
Delmotte, M., Kotlyakov, V.M., Legrand, M., Lipenkov, V.Y., Lorius, C., Pépin, L., Rithz, C., Saltzman, E., Stievenard, M., 1999. Climate and atmospheric history of the past 420,000 years from the Vostok ice core, Antartica. Nature, 399.

Plaziat, J.C., Boltzer, A., Choukri, A., Conchon, O., Freytet, P., Orszag-Sperber, F., Raguideau, A., Reyss, J.L., 1998. Quaternary marine and continental sedimentation in the northern Red sea and Gulf of Suez (Egyptian coast): influences of rift tectonics, climatic changes and sea-level fluctuations. In: Purser, B.H., Bosence, D.W.J. (Eds.), Sedimentation and tectonics of Rift Basins: Red Sea-Gulf of Aden. Chapman \& Hall, London, pp. 537-573.

Radtke, U., 1985. Untersuchungen zur zeitlichen Stellung mariner Terrasen und Kalkrusten auf Fuerteventura (Kanarische Inseln, Spanien). Kieler geographische Schriften 62, 73-95.

Sacco, F., 1893. I Molluschi dei terreni Terziarii del Piemonte e della Liguria. XIV, Reale Accademia de Scienze, Torino, 38 p.

Shackleton, N.J., Opdyke, N.D., 1973. Oxigen isotope and paleomagnetic stratigraphy of ecuatorial Pacific core V28-238: oxigen isotope temperature and ice volumes on a $10^{5}$ year and $10^{6}$ year time scale. Quaternary Research 3, 39-55.

Shackleton, N.J., Opdyke, N.D., 1976. Oxigen isotope and paleomagnetic stratigraphy of Pacific core V28-239. Late Pliocene to latest Pleistocene. Geological Society of America Memoir 145, 449-464.

Steiger, R.H., Jaeger, E., 1977. Subcommission on Geochronology: convention on the use of decay constants in geo- and cosmochronology. Earth Planetary Science Letters 36, 359-362.

Stuiver, M., Reimer, P., 1993. Extended ${ }^{14} \mathrm{C}$ data base and revised CALIB $3.0{ }^{14} \mathrm{C}$ calibration program. In: Stuiver, M., Long, A., Kra, R.S. (Eds.), Calibration 1993. Radiocarbon, Vol. 35, pp. 231-237.

Tinkler, K.J., 1966. Volcanic Chronology of Lanzarote (Canary Islands). Nature 209, 1122-1123.
Waller, T.R., 1980. Scanning Electron Microscopy of Shell and Mantle in the Order Arcoida (Mollusca: Bivalvia). Smithsonian Contribution to Zoology 313, Smithsonian Institution Press, Washington (DC), USA, $58 \mathrm{pp}$.

Wehmiller, J.F., Miller, G.H., 1990. Amino acid racemization geochronology. In AMQUA-CANQUA Joint Meeting, Short Course 3, Examples and Critiques of Quaternary Dating Methods, June 4-6, University of Waterloo, Canadá, pp. 1-57.

Zazo, C., Goy, J.L., Dabrio, C.J., Bardají, T., Somoza, L., Silva, P.G., 1993. The Last Interglacial in the Mediterranean as a model for the Present Interglacial. Global Planetary Change 7, 109-117.

Zazo, C., Hillaire-Marcel, C., Goy, J.L., Ghaleb, B., Hoyos, M., 1997. Cambios del nivel del mar-clima en los últimos $250 \mathrm{Ka}$ (Canarias Orientales). Boletín Geológico y Minero 108 (4/5), 159-169.

Zazo, C., Silva, P.G., Goy, J.L., Hillaire-Marcel, C., Ghaleb, B., Lario, J., Bardají, T., González, A., 1999. Coastal uplift in continental collision plate boundaries: data from the Last Interglacial marine terraces of the Gibraltar Strait area (south Spain). Tectonohysics 301, 95-109.

Zazo, C., Goy, J.L., Hoyos, M., Hillaire-Marcel, C., González, J.A., Ghaleb, B., Soler, V., Dabrio, C.J., Gillot, P., 2000a. A raised marine terraces recording oceanic warm conditions and uplifting trend during Pliocene and Quaternary (Eastern Canary Islands, Spain). Quaternary International 202, 63-64.

Zazo, C., Goy, J.L., Hillaire-Marcel, C., González-Delgado, A., Dabrio, C.J., Soler, V., Bardají, T., Gillot, P.Y., Silva, P.G., González-Hernández, F., Làrio, J., 2000b. Raised marine terraces as proxies for sea-level changes see-surface conditions (Atlantic-Mediterranean, Spain). In: Schnack, E., Murray-Wallace, C. (Eds.), Patagonia 2000 International Conference on Coastal Interactions during Sea-Level Highstands. Abstracts Vol. 87-89. 